\title{
ПАНДЕМИЈА НОВОГ КОРОНАВИРУСА: ПОСЛЕДИЦЕ У МЕЂУНАРОДНОЈ ЗАЈЕДНИЦИ
}

\author{
проф др. Жарко Обрадовић ${ }^{1}$
}

Апстракт: За врло кратко време вирус ковид 19 се из Кине проширио готово на целу планету и постао глобална здравствена опасност за све људе широм света. Пандемија новог вируса још увек траје, изазивајући широки спектар последица на глобалном и на локалном плану. Рад ће покушати да одговори на питање о степену и дубини промена које је изазвала пандемија новог вируса у свету и унутар појединих држава. На глобалном плану приметан је застој глобализације због прекида размене људи и роба. У борби против ширења новог вируса затворене су границе држава, прекинут је саобраћај (авионски, друмски, железнички), прекинута је или битно смањена производња у компанијама широм света, па је скоро потпуно заустављена размена роба међу државама. На упозорења Светске здравствене организације о опасностима и мерама спречавања ширења вируса државе су различито реаговале (ограничено је кретање и окупљање људи или су уведене либералне мере), чак и унутар регионалних организација држава, као нпр. у Европској унији. Нестало је солидарности међу државама у погледу испоруке потребних медицинских апарата и опреме. Свако се трудио да обезбеди прво себе потребним апаратима и опремом, па тек онда да се та опрема учини доступном другом. Како се повећавао број заражених и преминулих људи од новог вируса, све су чешће биле расправе унутар држава, и на глобалном нивоу, о квалитету здравственог система, о предузетим мерама и последицама, начинима ширења вируса, размени информација, али и о бројним другим питањима (о моделима функционисања економија држава, улози државе у борби против пандемије, питању вакцинације, монополу појединих држава и компанија у производњи одређених лекова и др.). Отворено је и питање да ли је пандемија новог вируса означила уједно и почетак појављивања НР Кине као нове економске суперсиле, уместо Америке. Промене изазване пандемијом су бројне на унутрашњем и на међународном плану. И нису завршене, јер је нови вирус, са већим или мањим интензитетом, још увек присутан. Упркос томе, постоји општа потреба да се на нека отворена питања већ дају одговори због решавање актуелних питања и због будућих дешавања.

Кључне речи: ковид 19, пандемија, међународна заједница, држава, последице

1 Универзитет у Београду, Факултет безбедности; е-mail: obradovic.zarko60@gmail.com 


\section{УВОД}

Почетком јануара 2020. године, када је у Кини код једног броја људи у подручју пијаце морске хране у Вухану, констатовано постојање „упале плућа непознатог узрока“, тешко да је било ко унутар НР Кине, а поготову на међународном плану, могао предвидети све последице новог вируса. Најпре полако, а онда све брже и брже, са једне на другу особу, преко једне до друге државе, нови вирус, у међувремену назван ковид 19, постао је узрочник проглашења пандемије и бројних промена на унутрашњем и међународном плану, чију дубину још увек није могуће у потпуности сагледати.

Светска здравствена организација је 11. марта, прогласила пандемију ${ }^{2}$ вируса ковид 19. Тада је широм света већ било заражено више од 116.000 особа. Три недеље касније, 2. априла број људи заражених ковидом 19 прешао је један милион, и било је преко 50.000 умрлих ${ }^{3}$. Непуна три месеца касније, дакле шест месеци од појаве новог вируса и три и по месеца након што је проглашена пандемија, на дан 28. јун у свету је било заражено више од 10 милиона људи, а број умрлих је био преко 502.000 особа 4 . Само три недеље касније, 21. јула, у свету је забележено више од 15 милиона заражених особа у 213 држава света 5 . Убрзање ширења пандемије потврдио је податак да је само пар дана касније, 25. јула, у свету било заражено преко 16 милиона особаб.

Међу државама највећи број оболелих од ковида 19 налази се у Сједињеним Америчким Државама - 4.101.308 особа. Нажалост, САД су водећа земља у свету по броју умрлих од ковида 19. Њихов број је 22. јула износио 146.192 особе7. Укупан број особа преминулих од ковида 19 у свету истог дана износио је 630.750 особа.

Светска здравствена организација је после проглашења пандемије своју активност свела на размену информација, давање препорука државама како се борити против ковида 19 и упозорења о опасности коју вирус представља за свет. Средином априла С30 је оценила да је „коронавирус десет пута смртоноснији од свињског грипа“, пандемије из 2009. године8. Како се пандемија ширила, и оцена опасности од новог вируса је расла. Средином јуна генерални секретар С30 је

2 Пандемија мед. епидемија која се простире на више континената, према: Velika opšta ilustrovana enciklopedija Larousse: Tom 4, Dopunjeno srpsko izdanje, Mono i Manjana, Beograd, 2010, str. 2045.

3 „Корона вирус: највећа криза 21. столећа“, Недељник, бр. 431, 2020, стр. 17.

4 „COVID-19 Coronavirus pandemic", Worldometer, https://www.worldometers.info/coronavirus/, 28/06/2020.

5 Ибид, Наведено према: „15.000.000“, Б92, 21. јул 2020, https://www.b92.net/info/vesi/index.php?yyyy=2020\&mm=07\&dd=21\&nav_category=78\&n av_id=1709563, 21/07/2020.

6 „COVID-19 Coronavirus pandemic”, Worldometer, https://www.worldometers.info/coronavirus/, 25/07/2020.

${ }^{7}$ Ибид, 23/07/2020.

8 „Директор СЗО: корона вирус је десет пута смртоноснији од свињског грипа“, РТС, 14. април 2020,

https://www.rts.rs/page/stories/sr/\%D0\%9A\%D0\%BE\%D1\%80\%D0\%BE\%D0\%BD\%D0\% B0\%D0\%B2\%D0\%B8\%D1\%80\%D1\%83\%D1\%81/story/3138/koronavirus-u-

svetu/3922211/szo-gebrejesus-koronavirus.html, 23/07/2020. 
изјавио да „свет никада није видео овако нешто од грипа 1918. године, односно шпанског грипа, који је убио најмање 50 милиона људи“9.

Државе су примениле различите мере у борби против коронавируса, па је логично и број заражених и преминулих лица био различит ${ }^{10}$. Вирус још увек није заустављен и шири се у готово свим државама света. Бројке о морталитету у свакој држави подложне су променама, тако да ће се њихов тачан број (а тиме и оцена ефикасности мера̂ држава против ковида 19) знати тек кад пандемија престане и вирус нестане.

О новом вирусу се много тога зна. У међувремену од појаве ковида 19 започета су озбиљна истраживања како би се утврдила природа вируса, начин његовог испољавања и, наравно, како га зауставити ${ }^{11}$. 0 броју чланака који се на различите начине баве новим вирусом (узроцима настанка, начинима ширења, симптомима испољавања, последицама деловања - медицинским и друштвеним и др.) тешко је говорити, с обзиром на то да их има јако много. Могли бисмо закључити да се о вирусу ковид 19 све или скоро све зна. Ипак није тако. После месец дана од проглашења пандемије новог вируса, и на основу до тада изнетих сазнања о ковиду 19, чувени немачки филозоф Јирген Хабермас је рекао: „Толико знања о нашем

\footnotetext{
9 „Невидљив, веома мали вирус који изазива расуло“, Б92, 12. јун 2020.

https://www.b92.net/info/vesti/index.php?yyyy=2020\&mm=06\&dd=12\&nav_category=78\& nav_id=1694734, 23/07/2020.
}

10 Међу стручњацима постоји сагласност да је стопа морталитета једини валидан критеријум који даје могућност да се упореди ефикасност мера држава, односно упореди једна држава са другом. Према подацима са почетка јуна 2020. године морталитет у Србији био је 3,5/100.000 становника, тј. међу нижим у Европи и испод светског просека, који је износио 4,6/100.000. Према истим подацима морталитет је у Хрватској био 2,5/100.000, у Црној Гори 1,4/100.000, Босни и Херцеговини преко 4/100.000, а у Словенији и Северној Македонији преко 5/100.000. Разлика међу поменутим државама у броју преминулих особа постоји, али се „значај података“ може разумети тек када се они упореде са земљама које имају далеко већи број становника. Примера ради, стопа морталитета у Великој Британији и Италији била је изнад 50/100.000, у Сједињеним Америчким Државама 31/100.000, а у Русији 2,8/100.000. Наравно да се и ове бројке могу подврћи додатној анализи (старосна доб преминулих, стање здравља пре оболевања од короне и др.), али оне јесу важан показатељ да ли су државне мере успеле да спрече најтрагичније последице присуства ковида 19. Сви подаци су наведени према: „Ово је тек крај почетка (интервју са др Владимиром Петровићем, епидемиологом)“, Недељник, бр. 438, 2020, стр. 30-33.

11 Почетком јула у више држава света било је више од 140 потенцијалних вакцина које се истражују. За најмање 30 се очекује да ће започети тестирање на људима ове године, док се 16 потенцијалних вакцина већ тестира на људима. Процене стручњака о спремности вакцина за употребу крећу се од јануара 2021, до 2022, па чак и 2023. године. Наведено према: J. Р. „Пола године короне: Потресла је свет из темеља, крај јој се не назире, а на ових 10 кључних питања још немамо одговоре“, Блиц, 6. јул 2020, https://www.blic.rs/vesti/svet/pola-godine-korone-potresla-je-svet-iz-temelja-kraj-joj-se-nenazire-a-na-ovih-10/gqrchk9, 25/07/2020. 
незнању... (о корони - прим. аут.)... још никад није било.“12 Да се сазнања о ковиду 19 нису много померила унапред, потврдио је и члан Кризног штаба Републике Србије, епидемиолог др П. Кон, који је 25. јуна констатовао да нам је „овај вирус показао да ништа не знамо о њему.“13

Не желећи да се даље бавимо овим научним феноменом везаним за вирус ковид 19 („знањем о незнању“), а чињенице говоре да се лекови испитују, вакцине најављују, а вирус и даље шири светом, покушаћемо да у односу на доступне чињенице представимо ефекте појаве и ширења овог вируса на међународном нивоу.

\section{ДЕШАВАЊА НА ГЛОБАЛНОМ НИВОУ}

Када се нови вирус појавио у Кини, остале државе су реаговале прилично равнодушно. Нови вирус је схваћен као „кинеска ствар“, па је у складу са тим Кини остављено да сама тражи одговоре и решења како савладати ковид 19. Код представника више држава, као и код појединих здравствених радника, однос према новом вирусу је у првим данима, па и недељама његовог настанка и ширења имао карактеристике игнорисања, неразумевања, потцењивања, па чак и претеране самоуверености ${ }^{14}$. Када је вирус прешао границе Кине и стигао у друге земље, дошло је и до промена у њиховом понашању, тј. у оцени опасности новог вируса.

Реакција Европске уније на појаву ковида 19 била је спора и непотпуна. Иако је прво упозорење у Европи на појаву новог вируса у Кини издато још 9. јануара, и у међувремену одржано неколико састанака на којима се разговарало о вирусу, до првог заједничког састанка министара здравља земаља Европске уније на ком би се усагласиле мере против вируса дошло је тек 13. фебруара15.

Пандемија коронавируса се ширила у земљама Европске уније брже него што је ико очекивао. Број заражених се убрзано повећавао. Зато је Светска здравствена

12 „Јирген Хабермас о корони: Толико знања о незнању још никада није било“, Ecnpeco, 22. април 2020, https://www.espreso.rs/kultura/knjiga/548349/jurgen-habermas-o-koronitoliko-znanja-o-neznanju-još-nikada-nije-bilo, 23/04/2020.

13 „Кон за РТС: Овај вирус је показао да ништа не знамо о њему“, РTC, 25. јун 2020, https://www.rts.rs/page/stories/ci/\%D0\%9A\%D0\%BE\%D1\%80\%D0\%BE\%D0\%BD\%D0\%B 0\%D0\%B2\%D0\%B8\%D1\%80\%D1\%83\%D1\%81/story/3131/koronavirus-u-

srbiji/3998636/koronavirus-predrag-kon-kovid-19-radomir-jankovic.html, 25/06/2020.

14 Тако је Доналд Трамп, председник Сједињених Америчких Држава, на митингу у Хемпширу одржаном 4. фебруара рекао да ће „до априла, у теорији, кад постане мало топлије, чудом нестати вирус“. Двадесет дана касније, приликом посете Индији, Трамп шаље поруку да је „корона вирус под контролом у САД и да берза почиње да му изгледа добро“. Наведено према: „Корона вирус највећа криза 21. столећа“, ор. cit., стр. 13.

15 Наведено према: Т. Г. „Коначно је откривено зашто нико није помогао Италији: Европа је 26. фебруара схватила шта се спрема, а ево како су све државе одреаговале“, Блиц жена, 15. јул 2020, https://zena.blic.rs/lifestile/konacno-je-otkriveno-zasto-niko-nije-pomogaoitaliji-evropa-je-26-februara-shvatila/0k57gp8, 15/07/2020. 
организација 13. марта објавила да је „Европа епицентар глобалне пандемије“16. Европска унија је реагујући на ширење пандемија 17. марта затворила своје спољне границе, а потом су границе затворене и унутар саме Европске уније. Слобода кретања људи и отворене границе држава чланица ЕУ, симболи Европске уније, заустављени су у страху од ширења пандемије. Улазак и излазак унутар држава ЕУ, као и за странце, постојао је само у неким изузетним случајевима (медицински, економски и државни разлози) 17.

Прекид саобраћаја (авионског, железничког, поморског и путног), делимично или у потпуности, довео је до прекида кретања људи, робе и економске сарадње. Прекид путовања међу државама на спољном плану праћен је пакетом различитих мера на унутрашњем плану, све са намером да се заустави ширење новог вируса и заштитити безбедност грађана. Значајан број држава донео је одлуке о увођењу ванредног стања. Већина држава уводи ригорозне мере забране окупљања и изласка из кућа. Мали број држава, као на пример Шведска, примениле су либералне мере, слободе кретања и окупљања, уз поштовање правила социјалне дистанце, тј. постојање растојања међу људима. Шведска је, за разлику од других чланица Европске уније, које су затвориле своје границе за грађане других држава, дозволила слободан пролаз за све странце18. Различите мере имале су и различите последице, боље и нажалост горе. Било је и држава које су се у почетку определиле за либералнији приступ у борби против вируса, као нпр. Велика Британија, али су због наглог повећања броја заражених особа прешле на оштрије мере.

Затварање граница и страх од последица вируса до краја су оголили карактер понашања држава у међународној заједници. Државе су примарно бринуле о својим интересима (како да се сачувају здравствени систем и грађани), па тек после о другим, заједничким обавезама. Нестало је солидарности међу државама чак и унутар Европске уније, као заједнице држава ${ }^{19}$. Тако је на нивоу Европске уније донета одлука о забрани извоза различитих врста медицинске опреме. Државе кандидати за чланство у Европску унију су биле изузете од могућности набавке медицинске опреме унутар ЕУ. Касније, услед заједничког захтева држава

16 Ибид.

17 Део граничних прелаза је остао отворен, као нпр. између Немачке, Аустрије и Швајцарске, за раднике који су живели у једној, а радили у компанијама друге државе. Наравно, прелазак границе је био могућ уз потврду предузећа да је присуство радника неопходно. Видети детаљније у Никола Радишић, „Портпарол ЕК за Н1: Објавићемо смернице како поново путовати широм Уније“, N1, 21. април 2020, http://rs.n1info.com/Svet/a591525/Evropski-dopisnik-N1-izvestava-iz-Sengena.html, $21 / 04 / 2020$.

18 Наведено према: Горан, Чворовић, „Све више рампи кроз отворену Европску унију: Нико не зна шта га чека ако крене на пут“, Новости, 16. jun 2020, https://www.novosti.rs/vesti/planeta.299.html:870883-Sve-vise-rampi-kroz-otvorenu-Evropsku-uniju-Niko-ne-zna-sta-ga-ceka-ako-krene-na-put, 16/06/2020.

19 Наведено према: „Француски стручњак: Корона је открила фаталну пукотину у ЕУ“, Спутњик Србија, 28. април 2020, https://sptnkne.ws/CkPU, 28/04/2020. 
кандидата ${ }^{20}$ и бројних критика унутар и ван ЕУ, та одлука је промењена, па су тако државе Западног Балкана добиле могућност набавке заштитне медицинске опреме из земаља ЕУ21. Али није то био само однос ван ЕУ према државама кандидатима. И међу чланицама ЕУ није постојала солидарност, нити спремност да се пружи помоћ најугроженијим чланицама. Питање солидарности међу чланицама ЕУ постало је и питање будућности уније. Али солидарности није било 22. У данима и недељама, крајем фебруара и почетком марта, када је северни део Италије био погођен коронавирусом (уз огроман број заражених и преминулих лица) и када ни пацијенти, ни здравствени радници нису имали адекватну медицинску опрему (заштитна средства, медицинске уређаје и др.), бројни апели за помоћ према ЕУ са италијанске стране остали су без одговора23. То је изазвало незадовољство италијанских грађана и неповерење према Европској унији ${ }^{24}$. Председник Владе Италије Ђузепе Конте је изјавио да „Европска унија није помогла његовој земљи“25. Да је ЕУ тога свесна, потврђује и каснија изјава Урсуле Фон де Лајен, председнице Европске комисије, да се

20 Министри спољних послова Албаније, Босне и Херцеговине, Косова, Црне Горе, Северне Македоније и Србије упутили су писмо високом представнику ЕУ за спољну политику и безбедност Ђ. Борељу, комесару за трговину Ф. Хогану и европском комесару за суседску политику и преговоре о проширењу О. Вархељију, у ком су тражиле да буду изузете од одлуке ЕУ да забрани набавке медицинске опреме. Наведено према: „Западни Балкан тражи од ЕУ да буде изузет из рестрикција за медицинску опрему“, N1, 9. април 2020, http://rs.n1info.com/Vesti/a587383/Zapadni-Balkan-trazi-od-EU-da-bude-izuzet-izrestrikcija-za-medicinsku-opremu.html, 10/04/2020.

${ }^{21}$ Наведено према: „Борељ: Извоз медицинске опреме на Западни Балкан, без посебних дозвола“, РТC, 20. април 2020.

https://www.rts.rs/page/stories/sr/\%D0\%9A\%D0\%BE\%D1\%80\%D0\%BE\%D0\%BD\%D0\% B0\%D0\%B2\%D0\%B8\%D1\%80\%D1\%83\%D1\%81/story/3138/koronavirus-usvetu/3928745/borelj-eu-zapadni-balkan-oprema-izvoz-.html, 20/04/2020.

22 Председник Владе Шпаније П. Санчез, која је као и Италија имала велики број особа заражених и преминулих од ковида 19 и која такође није имала довољно медицинске опреме и апарата, а помоћи од осталих чланица ЕУ није било - тим поводом је изјавио: „Будућност Европе је у питању. Наши грађани умиру и наше болнице су пренатрпане. Или ћемо узвратити непоколебљивом солидарношћу, или ће наша унија пропасти... Солидарност међу Европљанима је кључни принцип ЕУ уговора. ..Без солидарности не може да буде кохезије, а без кохезије биће незадовољство и кредибилитет европског пројекта биће жестоко оштећен... Морамо да делујемо сада или никада, јер управо у овом моменту сама Европа је у питању“., Наведено према: Никола, Врзић, „Европска будућност Србије“, Печат, бр. 613, 2020, стр. 21.

${ }^{23}$ Када је Рим 28. фебруара активирао „цивилни заштитни механизам“ ЕУ, како би Италија могла добити различиту заштитну личну опрему, осталих 26 чланица ЕУ нису реаговале. Видети детаљније; Ибид.

24 Истраживања јавног мњења су показала да је чак 88 посто Италијана сматрало да их је Европска унија за време панадемије оставила саме. Наведено према: Светлана Васовић Мекина, „Покради ближњег свог“ Печат, бр. 614, 2020, стр. 32.

${ }^{25}$ Наведено према: Мирјана, Черкевец, „Због захвалности Кини и Русији, ЕУ прети Србији“, Политика, бр. 38228, 23. април 2020, стр. 1. 
„Европска унија огрешила о Италију“26. Уместо Европске уније, помоћ у медицинској опреми Италији је стигла од НР Кине и Руске Федерације. У појединим градовима Италије, као одраз односа према помоћи из Русије и одсуства реакције ЕУ, уместо застава ЕУ стављене су заставе Руске Федерације27.

Унутар ЕУ у већини држава није било довољно заштитне опреме или је постојећој опреми истекао рок. Уместо (евентуалног) централизованог снабдевања, свака земља је настојала да сама набави потребну опрему. Поверење, јединство и солидарност међу чланицама ЕУ су се изгубили у трци да се осигура медицинска опрема за „своје грађане“. Колико је појединачни интерес држава чланица имао предност у односу на општи (ЕУ), показује и „скандал са пошиљком заштитне опреме за целу Европу, коју су Немачка и Француска просто присвојиле“28. Пољска и Чешка, су тако медицинску опрему купљену у Кини за потребе италијанских грађана једноставно преузеле. У случају Пољске реч је била о 23.000 заштитних маски, које су „грешком царине“ најпре одузете, па касније на захтев Италије враћене, а читав случај је од стране Пољске окарактерисан као лажна вест. У Чешкој државни органи су узели и расподелили својим болницама 680.000 маски које су биле купљене за потребе Италије. И овај случај је проглашен „случајном грешком“, али довољно говори, као и у случају Пољске, о стању односа међу чланицама ЕУ29. Неке чланице ЕУ су започеле са планирањем сопствене производње маски (Француска), док су друге започеле куповину састојака за лекове (Белгија и Холандија).

Ипак, случајева непостојања солидарности међу државама у борби против ковида 19 и отимања медицинске опреме намењених другим државама није било само међу чланицама Европске уније, већ и у другим деловима света. Израел и Немачка су тако остали без неколико пошиљки медицинских апарата и заштитних средстава које су на „чудан начин“ „испоручени“ другим државама, у овом случају Сједињеним Америчким Државама и једној заливској (арапској) земљи ${ }^{30}$. Израел је ради набавке и заштите потребне медицинске опреме ангажовао и припаднике обавештајне организације Мосад ${ }^{31}$. У преотимању заштитне опреме, тј. плаћању по далеко већој цени од уговорене, нарочито су били активне САД, које су робу купљену у Кини за потребе Француске, Немачке и Канаде „преусмериле“ на

\footnotetext{
${ }^{26}$ Ибид, стр. 6.

27 Ибид, стр. 1.

${ }^{28}$ Наведено према: Ибид.

${ }^{29}$ Наведено према: Светлана Васовић Мекина, „Покради ближњег свог“, ор. cit., стр. 33.

30 Видети детаљније: Раде Мароевић, „Битка међу државама за маске и респираторе као шпијунски трилер“, РТC, 2. мај 2020, https://www.rts.rs//page/stories/ci/\%D09A\%.../story3135/koronavirus-u-svetu3940071/koronavirus-svet-maske-nabavka-mosad-vojska.html, 23/07/2020.

31 Ибид.
} 
америчко тло 32 . Поред тога што је преотела заштитну робу од Канаде, Америка је забранила извоз медицинске опреме у Канадуз3.

Погубне последице присуства ковида 19 по економију држава чланица ЕУ виделе су се већ почетком маја. О дубини економске кризе најбоље говори оцена П. Ђентилонија, европског комесара за економију, који је констатовао да је „ЕУ ушла у најдубљу економску рецесију у својој историји“ (подвукао Ж. О.) и да „Европа пролази кроз економски шок без председана од Велике депресије (тридесетих година прошлог века)“34. Процена пада економских активности на нивоу Европске уније за 2020. годину због тога износи 7 одсто. Међу државама највећи економски пад се предвиђа за Грчку, Италију и Шпанију (пад већи од девет одсто), затим Француску (осам одсто) и друге чланице. Најмањи економски пад пројектован је у Пољској $(4,25$ одсто). То ће изазвати и даљи пораст незапослености унутар ЕУ (са 6,7 одсто у 2019. години на 9 одсто у 2020). Тмурне процене економске ситуације у ЕУ употпуњује и најава пада страних инвестиција од око 880 милијарди евра ${ }^{35}$. Постало је јасно да Европска унија мора да нађе решење како да заустави економски пад држава чланица изазван короном и покрене нови развојни циклус. Разговори обављени почетком маја међу чланицама ЕУ су показали да нема заједничког одговора на економску кризу у ЕУ. Разговори о новцу су суштински отворили питање јединства и даље судбине Европске уније ${ }^{36}$. Чланице ЕУ се наиме нису могле договорити о финансијском пакету помоћи државама, критеријумима поделе и начинима (не)враћања новца (да ли су у питању кредити или је реч о бесповратној новчаној помоћи) ${ }^{37}$.

Почетком јула немачка канцеларка А. Меркел је констатовала да „се Европа суочава са најтежом ситуацијом у својој историји“ и да пандемија „ставља на тест способност Европе да се држи заједно“38. Њене речи, иако засноване на понашању чланица ЕУ у месецима када је пандемија почела, добиле су још више на значају током разговора чланица ЕУ о формирању фонда за ублажавање економских последица пандемије. Тада се видело да јединства у ЕУ нема и да оно зависи од степена интереса које чланице обезбеде у „међусобном договарању“.

32 Видети детаљније: Светлана Васовић Мекина, „Покради ближњег свог“, op. cit., стр. 32.

${ }^{33}$ Ибид.

34 Наведено према: „Брисел: ЕУ у историјској рецесији“, Политика, 8. мај 2020, стр. 2.

35 Сви подаци наведени према: Ибид.

36 Видети детаљније: Тања, Вујић, „СОС корона прети да дезинтегрише ЕУ“ Политика, 18. јул 2020, http://www.politika.rs/scc/clanak/458634/SOS-korona-preti-da-dezintegrise-EU, 24/07/2020.

37 Видети детаљније: „Из пандемије се рађа нови глобални поредак“, Политика, 4. мај 2020, стр. 6.

38 Наведено према: „Меркел: Европа се суочава са најтежом ситуацијом у историји“, РТС, 2. јул 2020, https://www.rts.rs/page/stories/ci/\%D0\%9A\%D0\%BE\%D1\%80\%D0\%BE\%D0\%BD\%D0\%B 0\%D0\%B2\%D0\%B8\%D1\%80\%D1\%83\%D1\%81/story/3135/koronavirus-usvetu/4006692/angela-merkel-koronavirus-evropa-najteza-situacija-u-istoriji.html, 02/07/2020. 
Два и по месеца од почетка првих разговора, после више преговора и уз бројне уступке према појединим чланицама, челници држава чланица ЕУ су на самиту у Бриселу одржаном 17-20. јула постигли договор о структури фонда за помоћ короном најугроженијих чланица уније. Од 750 милијарди евра средстава фонда, која ће бити део буџета ЕУ за период 2021-2027. год, 390 милијарди евра је бесповратна помоћ чланицама, а 360 милијарди је у облику повољних зајмова. Преговори око новца су показали да упркос заједничким проблемима које је изазвао коронавирус, државе чланице пре света воде бригу о својим посебним интересима. Нема јединства, солидарности, подршке или помоћи. Само интерес. Зато решење о структури новца фонда није могло ни бити нађено док није прихваћено више различитих предлога чланица. Холандија, Шведска, Данска, Аустрија и Финска су тражиле да се смањи сума бесповратне помоћи чланицама са 500 на 390 млр. евра и у томе су успеле. Поред тога, постигле су и повећање стопе повраћаја новца из буџета ЕУ. Мађарска и Пољска, уз прећутну подршку Словеније и Литваније, одустале су од права вета на целу суму помоћи (750 млр. евра) док нису добиле гаранције да коришћење новца неће бити повезано са оценом владавине права у њиховим земљама. Немачка и Француска, као водеће земље ЕУ, одустале су од првобитног предлога структуре новца фонда и прихватиле захтеве других чланица, да би се сачувало „јединство“ ЕУз9. Остале земље ЕУ су без сумње имале интерес да се до заједничког решења дође, јер је то за њих значило значајну финансијску добит за помоћ економијама посрнулим од последица пандемије.

Вирус ковид 19 је погодио и две економски најмоћније земље света: Кину, у којој је и настао, и Сједињене Америчке Државе, на коју се проширио. Кина и САД су на различите начине реаговале у намери да спрече његово ширење и да санирају последице, па су и резултати били различити. Због значаја ових двеју држава за стање односа у међународној заједници, последице ковида 19 ће несумњиво утицати на међусобни однос ових двеју држава, као и на глобални поредак моћи држава.

Када се фебруара месеца вирус појавио у Америци,, председник САД Доналд Трамп је давао изјаве којима је умањивао претње новог вируса. Најавио је наиме „брзу победу над вирусом“40. Поред тога, Трамп није у довољној мери прихватао мишљење струке у погледу мера које треба применити у области здравствене заштите људи, нпр. да се улаже у тестирање и апарате за дисање ${ }^{41}$. Неке мере

39 Сви подаци наведени према: „Баснословни договор Европске уније уз папрене уступке“, „Господин „не“ против Меркелове и Макрона“, Политика, 22. јул 2020, стр. 2.

40 Наведено према: Жарко Ракић, „Трампу сви криви, највише Кина“, Политика, 17. мај 2020, http://www.politika.rs/scc/clanak/454284/Pogledi/Medunarodni-pregled/Trampusvi-krivi-najvise-Kina, 21/07/2020.

41 Наведено према: „Трампова предвиђања пропала, корона вирус убио више Американаца него ратови у Вијетнаму и Кореји“, Б92, 26. мај. 2020, https: //www.b92.net/info/vesti/index.php?yyyy=2020\&mm=05\&dd=26\&nav_category=78\& nav_id=1687846, 26/05/2020. 
заштите је чак отворено игнорисао: готово цело време дејства ковида 19 није говорио у прилог значаја ношења маске у сузбијању пандемије, нити је маску лично носио (сем у пар изузетака), да би после веома брзог ширења ковида 19 и повећања броја заражених и преминулих особа 13. марта прогласио ванредно стање. Трамп је давао „чудне“ изјаве о могућем броју жртава пандемије, као нпр. „да би се 100.000 мртвих од последица коронавируса у САД-у могло сматрати добро обављеним послом“42 (подвукао Ж.О.). Сједињене Америчке Државе су врло брзо постале „водећа“ држава у броју случајева заражених коронавирусом и броју преминулих особа. Број жртава од короне је 26. маја премашио 100.000 особа, што је био већи број „него што је погинуло америчких трупа у ратовима у Кореји и Вијетнаму“43. Три недеље касније, 16 јуна, број преминулих од пандемије износио је 116.526 људи, што је било више него што је Америка имала жртава у Првом светском рату (116.516 војника) ${ }^{44}$. Нажалост, тренд повећања броја заражених и преминулих особа због вируса ковид 19 настављен је несмањеном жестином током јуна и јула 45 .

Здравствени систем САД је под великим оптерећењем: собе у ургентним центрима су препуне, неки пацијенти се налазе у ходницима, пацијенти којима је потребан ваздух користе респираторе у јединицама хитне помоћи, медицинско особље (међу којима такође има заражених) ради у више смена ${ }^{46}$. Поједине државе као Њујорк нису могле постојећим капацитетима да пруже сву потребну негу особама зараженим од ковида 19. Недостајали су апарати и заштитна медицинска опрема за спречавање ширења пандемије и лечења оболелих.

42 Наведено према: „Трамп: 100 хиљада мртвих био би добро обављен посао“, N1, 30. март 2020, http://rs.n1info.com/Svet/a583395/Tramp-100-hiljada-mrtvih-bio-bi-dobro-obavljenposao.html, 21/07/2020.

43 Наведено према: „Трампова предвиђања пропала, корона вирус убио више Американаца него ратови у Вијетнаму и Кореји“, ор. cit.

44 Наведено према: „У САД више умрлих од короне него жртава у Првом светском рату“, Данас, 16. јун 2020, https://www.danas.rs/svet/u-sad-više-umrlih-od-korone-nego-zrtava-uprvom-svetskom-ratu/, 16/06/2020.

45 Од почетка јула нови талас пандемије је изазвао свакодневне „црне“ рекорде у повећању броја заражених у Сједињеним Америчким Државама. Почетком јула (2. јула) дневни пораст заражених износио је 48.000 особа. Тај број је 21. јула износио више од 70.000 нових случајева дневно. Наведено према: „Трамп верује да ће САД ускоро имати вакцину, нове мере на снази у Црној Гори“, РТC, 2. јул 2020 ,

https://www.rts.rs/page/stories/ci/\%D0\%9A\%D0\%BE\%D1\%80\%D0\%BE\%D0\%BD\%D0\%B 0\%D0\%B2\%D0\%B8\%D1\%80\%D1\%83\%D1\%81/story/3135/koronavirus-usvetu/4005733/koronavirus-svet-2-jul.html, 02/07/2020; Наведено према: „Више од 140.000 преминулих у САД; Словенија увела нове мере и у цркви“, РТС, 20. јул 2020,https://www.rts.rs//page/stories/ci/\%D0\%9A\%D0\%BE\%D1\%80\%D0\%BE\%D0\%BD \%D0\%B0\%D0\%B2\%D0\%B8\%D1\%80\%D1\%83\%D1\%81/story/3135/koronavirus-usvetu/4023047/koronavirus-svet-zaraženi-kovid-19-pandemija.html, 21/07/2020.

46 Видети детаљније: „Здравствени систем САД на ивици, пацијенти спавају по ходницима“, Б92, 19. јул 2020 , https: //www.b92.net/info/vesti/index.php?yyyy=2020\&mm=07\&dd=19\&nav_category=78\& nav_id=1708521, 19/07/2020. 
У покушају да пружи одговор на питање зашто је тако брзо почео да расте број заражених и преминулих особа у САД, „Њујорк тајмс“ наводи да су томе допринеле две грешке америчке владе. Прва грешка јесу нереалне и оптимистичне прогнозе, засноване на анализи Универзитета Вашингтона у Сијетлу, које нису узеле у обзир како ће грађани Америке поштовати мере социјалног дистанцирања, ограничења контаката и ношења маске (које нису у потпуности поштоване). Друга грешка је израда смерница о сузбијању пандемије које је израдила Бела кућа, која је препустила савезним државама право о предузимању одговарајућих мера против ковида 19 (а тиме и одговорност за последице). Како смернице нису биле обавезујуће, савезне државе су се понашале у складу са својим проценама, што је условило ширење пандемије ${ }^{47}$.

Упркос чињеници да је Америка по броју људи заражених и преминулим од ковида 19, прва међу државама у свету, Д. Трамп није мењао свој став да се америчко друштво не суочава са тешким проблемом. Трамп је говорио да ће коронавирус нестати и да је против увођења обавезног ношења маске на националном нивоу (иако су неке савезне државе увеле ту меру) ${ }^{48}$.

Поред потцењивања последица вируса ковид 19 од стране Д. Трампа (вербално и својим понашањем), и то у целом периоду откако се вирус проширио на територију САД, постоје још две „константе“ које су обележиле Трампов однос према пандемији. Прва је сталне оптужбе на рачун Кине (да је вирус „кинески“ и да Кина није објавила истините податке о опасности од новог вируса) ${ }^{49}$, што имплицира и одговорност Кине за ситуацију са короном у Америци. Друга је неповерење у рад Светске здравствене организације и податке које је СЗО износила у јавност. Трамп је оптужио С30 да „је стала на страну Пекинга“50 у погледу необјављивања свих података у фази настанка и ширења новог вируса. Због свега тога, Трамп је 15. априла одлучио да САД „привремено престану да финансирају Светску здравствену организацију „пошто није успела да спроведе неопходне и тражене реформе“ и због „веома лошег управљања пандемијом и

47 Видети детаљније: „Америка је направила две фаталне грешке са короном, доктори вичу: `Ово је ужас', а Трамп одговара: „Не шалим се!“, Блиц, 20. јул .2020, https://blic.rs/vesti/svet/amerika-je-napravila-dve-fatalne-greške-sa-koronom-virusomdoktori-vicu-ovo-je-uzas.a-tramp/619gsw9, 20/07/2020.

48 Наведено према: „Трамп о пандемији: Корона вирус ће нестати, на крају крајева ћу ја бити у праву“, Курир, 20. јул 2020, https://www.kurir.rs/planeta/3500721/tramp-opandemiji-korona-virus-ce-nestati-na-kraju-krajeva-cu-ja-biti-u-pravu, 20/07/2020.

49 Наведено према: „Трампова предвиђања пропала, корона вирус убио више Американаца него ратови у Вијетнаму и Кореји“, ор. cit. Исто; Жарко, Ракић: „Трампу сви криви, највише Кина“, ор. cit.

50 Наведено према: „Смена моћи се дешава пред нашим очима! ЕУ хитно захтева оштрију стратегију према Кини, јер Америка губи улогу највеће силе“, Новости, 26. мај 2020, https://www.novosti.rs/vesti/planeta.299.html:866901-Smena-MOCI-se-desava-pred-nasimocima-EU-hitno-zahteva-OSTRIJU-strategiju-prema-KINI-jer-Amerika-gubi-ulogu-NAJVECESILE, 26/05/2020. 
прикривања доказа о ширењу коронавируса“51. Таква одлука Трампа није наишла на одобравање у Европској унији. Напротив, Европска унија је најавила да ће наставити да подржава Светску здравствену организацију у „борби за спашавање живота и заустављање пандемије ковид 19“ и позвала САД да „преиспитају одлуку о прекиду веза и финансирања Светске здравствене организације“52. Кина је такође осудила одлуку САД, уз оцену да ће се на тај начин „ослабити капацитети С30 и поткопати међународна сарадња у борби против епидемије“53.

Доналд Трамп, председник САД, није се либио да кривицу за постојање и ширење новог вируса усмери у правцу НР Кине ${ }^{54}$. Државни секретар САД Мајк Помпео био је резолутан у ставу да постоје „огромни докази који показују да је вирус створио човек и да вероватно потиче из кинеске лабораторије“55. Био је то нови део укупне политике Трампове администрације заоштравања односа са Кином.

Трамп је очигледно „морао наћи“ кривца за стање пандемије у Америци, да не би себе сматрао одговорним. То је и „логично“ ако се зна да је Америка била у изборној години, када се бира председник, и да је Трамп желео да буде поново изабран и да (не)решавање пандемије могло определити бираче у избору будућег председника. Ово утолико пре што ни стање у економији земље, којој је Трамп предвиђао позитиван тренд, није ишло жељеним током. Конгрес је одобрио помоћ од две хиљаде милијарди долара америчкој економији како би спречио њен пад и отпуштање запослених. Са истим циљем, ради помоћи економији земље, Централна банка је смањила каматне стопе, повећала зајмове и откуп дугова56.

51 Наведено према: „Трампова предвиђања пропала, корона вирус убио више Американаца него ратови у Вијетнаму и Кореји“, ор. cit; Трамп: Прекидамо везе са С30; 'Опасна одлука` ВИДЕО“, Б92, 29. мај 2020,

https: //www.b92.net/info/vesti/index.php?yyyy=2020\&mm=05\&dd=29\&nav_category=78\& nav_id=1689459, 29/05/2020,

52 Наведено према: „ЕУ јасно ставила до знања на чијој је страни: Преиспитајте одлуку“ Б92, 30. мај .2020,

https://www.b92.net/info/vesti/index.php?yyyy=2020\&mm=05\&dd=30\&nav_category=78\& nav_id=1689672, 30/05/2020.

53 Наведено према: „ЕУ, Немачка и Кина осудиле одлуку САД да у јеку пандемије обуставе финансирање Светске здравствене организације“, Инсајдер, 15. април 2020, https://insajder.net/sr/sajt/vazno/17930/,15/04/2020.

${ }^{54}$ Наведено према: Јелена Каваја, „Стари митови оживели у новој верзији“, Политика, 18. мај 2020. http://www.politika.rs/scc/clanak/454300/Svet/Stari-mitovi-oziveli-u-novojverziji, 19/05/2020; „Шеф Института за вирусологију из Вухана открива све о пореклу корона вируса: Да ли ће ово ставити тачку на теорије завере?“, Новости, 25. мај 2020, https://www.novosti.rs/vesti/planeta.299.html:866877-Sef-Instituta-za-virusologiju-izVuhana-OTKRIVA-SVE-o-poreklu-korona-virusa-Da-li-ce-ovo-staviti-tacku-na-TEORIJEZAVERE, 25/05/2020.

55 Ибид.

56 Наведено према: „Демократе и републиканци договорили пакет помоћи вредан 2.000 милијарди долара“, N1, 25. март 2020, http://rs.n1info.com/Biznis/a581700/Paket-pomociu-SAD-za-saniranje-posledica-koronavirusa.html, 10/04/2020; „Пауел: Потребан додатни пакет помоћи Конгреса САД“, Радио Слободна Европа, 13. тај 2020, https://www.slobodnaevropa.org/a/30610288.html, 15/06/2020. 
Према подацима Америчког бироа за економске анализе, у САД-у је у првом кварталу 2020. године БДП процењен на минус 4,8 посто. То је био први негативни резултат још од 2014. године и најзначајнији пад „америчке привреде забележен још од рецесије 2008. године“57. Биро за економске анализе очекује и велики пад у личној потрошњи у првом кварталу 2020, и то од 7,6 процената уместо на минус 3,6\%, колико је било процењено 58 . Кад се оваквим негативним проценама дода и податак да се „укупан број људи који су од средине марта (до краја маја - прим. аут.) остали без посла због пандемије коронавируса попео на преко 40 милиона“59, онда се може разумети стање у економији земље, али и реаговање Д. Трампа.

Као велика и моћна економија, од које зависи и стабилност и развој светске економије, Кина је упоредо са заустављањем ширења ковида 19 донела економске мере како би обновила производњу и подстакла извоз. Мере владе су првенствено биле усмерене на област спољнотрговинске политике 60 , како би се кроз повећани извоз роба стабилизовао глобални ланац снабдевања и светска економија. Захваљујући овим мерама, Кина је успела да подстакне раст економије и да унутар тога произведе и допреми у Европу велике количине медицинске опреме за борбу против ковида 19, и то користећи теретне возове који повезују Кину и Европу, јер су остали међународни транспортни правци (ваздушни, бродски) били више или мање заустављени ${ }^{61}$. Кина је била једна од ретких држава која је исказала солидарност са другим државама у борби против вируса. Она је поклонила

57 Сви економски подаци наведени према „ЕУ и САД бележе историјски привредни пад“, PTC, 30. април 2020,

https://www.rts.rs/page/stories/ci/\%D0\%9A\%D0\%BE\%D1\%80\%D0\%BE\%D0\%BD\%D0\%B 0\%D0\%B2\%D0\%B8\%D1\%80\%D1\%83\%D1\%81/story/3175/ekonomija-i-

epidemija/3939477/sad-eu-privredni-pad-korona.html, 30/04/2020.

58 Ибид.

59 Наведено према: „Током пандемије у САД без посла остало више од 40 милиона људи“, PTC, 28. мај 2020,

https://www.rts.rs/page/stories/ci/\%D0\%9A\%D0\%BE\%D1\%80\%D0\%BE\%D0\%BD\%D0\%B 0\%D0\%B2\%D0\%B8\%D1\%80\%D1\%83\%D1\%81/story/3135/koronavirus-u-

svetu/3968723/koronavirus-kovid-19-sjedinjene-americke-drzave-rusija-italija-nemackafrancuska-slovenija-bugarska-iran.html, 28/05/2020.

60 Кинеска влада је у области спољнотрговинске политике усвојила више економских мера. Под један, „продубити отварање и међународну сарадњу“. Под два, предност у обнављању производње добила су предузећа која „имају важан утицај у глобалном ланцу снабдевања“ и одржавању његове стабилности. И под три, подржати кључна извозна предузећа, и кроз осигурање извозних кредита“, да што пре покрену производњу. Наведено према: „Кина се свим силама труди да оствари двоструку победу - и у превенцији и контроли епидемије и у обнављању рада и производње“, Политика, 22. јун 2020, стр. 8.

61 У периоду од јануара до априла број линија теретних возова између Кине и Европе порастао је за 24 и количина пошиљака које су транспортоване повећана је за $27 \%$. Из Кине је у Европу испоручено скоро осам хиљада тона противепидемијског материјала, што је представљало значајну помоћ државама у Европи у борби против вируса ковид 19. Наведено према: Ибид, стр. 8. 
великом броју држава значајне количине медицинске личне и заштитне опреме и апарата, потребне у борби против коронавируса. Поред тога, путем видеоконференција и слањем једног броја својих лекара са искуством у друге државе, Кина се упознала са начинима сузбијања ковида 19 и лечења заражених. За велики број држава то је представљало значајну материјалну и моралну помоћ и подршку у сузбијању пандемије коронавируса.

Обнављањем производње, уз поштовање општих мера против ковида 19 у фабрикама, канцеларијама и др. просторима (социјална дистанца међу људима, коришћење маски, дезинфекционих средстава и других мера ради превенције), Кина је успела да спречи други талас пандемије. То је био знак и за иностране компаније које производе или послују у Кини да наставе исто да раде. После прекида у јануару, фабрике компаније „Тошиба“ су почеле поново да раде током фебруара. Хилтон група је почетком маја наставила своје пословање, док су и остале мултинационалне компаније (БМВ, Тојота, Самсунг, Ербас и др.) такође најавиле наставак рада и производње 2. Обнављање рада страних компанија има велики значај за економију земље. То је уједно добар показатељ да је Кина и у време пандемије и даље привлачна за стране инвестиције, што код многих других држава, укључујући и бројне чланице ЕУ, није случај.

О утицају пандемије на економије САД и Кине и о променама у односима моћи на глобалном нивоу своју оцену је дао Ђ. Борељ, високи комесар Европске уније за спољну политику и безбедност. На видео-конференцији са немачким посланицима Борељ је истакао да „има назнака да Азија од САД преузима улогу центра глобалне моћи“ и да се „пандемија коронавируса може посматрати као тачка у којој је дошло до преласка моћи са Запада на Исток“63. Кад је реч о ЕУ, Борељ сматра да расте и притисак на ЕУ да изабере „страну“, да односи „Брисела и Пекинга нису увек засновани на поверењу, транспарентности и реципроцитету“ и да је ЕУ потребна „робуснија стратегија за Кину“.

Последице промена изазваних ковидом 19 на глобалној економској сцени признала је и А. Меркел, канцеларка СР Немачке: „Кина је постала главна економска сила.“64 Меркелова је у исто време, као потврду глобалне надмоћи Кине у односу на друге земље (а самим тим и концепта економске организације и

62 Видети детаљније: Ибид, стр. 8-9

63 Наведено према: „Смена владара света пред нашим очима! ЕУ хитно захтева оштрију стратегију према Кини, јер Америка губи у игри престола“, Курир, 25. мај 2020, https://www.kurir.rs/planeta/3470183/smena-vladara-sveta-pred-nasim-ocima-eu-hitnozahteva-ostriju-strategiju-prema-kini-jer-amerika-gubi-u-igri-prestola, 25/05/2020; „Смена моћи се дешава пред нашим очима! ЕУ хитно захтева оштрију стратегију према Кини, јер Америка губи улогу највеће силе“, ор. cit.

${ }^{64}$ Наведено према: Биљана Митриновић, „Меркелова: Не знамо да ли ће либерални систем победити“, Политика, 7. јул 2020, http://www.politika.rs/scc/clanak/457904/MerekelovaNe-znamo-da-li-ce-liberalni-sistem-pobediti, 08/07/2020. 
развоја кинеског друштва) ${ }^{65}$, изразила скепсу око будућности либералног модела односа у економији. Меркелова, наиме, сматра да западне земље још (увек) нису пружиле „апсолутни доказ да ће либерални систем ускоро победити“66. За Европу је потребно да има „заједничку европску позицију у односу на Кину“ и да европске земље треба да развијају политику која одражава „наше интересе и вредности“.

Прекид саобраћаја и кретања људи условио је и нови начин рада међународних организација и комуникације између држава. Уместо непосредних сусрета и контаката, седнице тела ОУН-а, ОЕБС-а, Савета Европе и др. организација су одржаване путем видео-везе. Светски лидери ће се ове године на заседању Генералне скупштине УН обратити јавности путем видео-порука. Билатерални сусрети највиших представника држава су сведени на најмању могућу меру или одржавани путем видео-веза. Конференције регионалног карактера или са мањим бројем учесника (нпр. конференција Европске уније се земљама Западног Балкана, или самит представника НР Кине и 17 држава централне и источне Европе), такође су одржане путем видеолинка.

\section{УЛОГЕ ДРЖАВЕ У БОРБИ ПРОТИВ КОВИДА 19}

Пандемија вируса ковид 19, односно спречавање њеног ширења, на јавну међународну сцену је поново афирмисала улогу државе. Као ретко кад у последњих пар деценија, држава је постала место где се одлуке доносе и простор где се оне примењују. Светска здравствена организација, као и друге међународне организације укључене у борбу против коронавируса, као и регионалне заједнице држава, доносили су само препоруке како се супротставити вирусу. Државе су на основу тих препорука доносиле конкретне одлуке и мере, које су имале и међународне и унутрашње последице. Државе су затвориле своје границе, прекинуле и ограничиле све врсте саобраћаја, а тиме и сарадњу са другим државама. На унутрашњем плану државе су увеле ванредно стање или друге мере на целој територији државе. По правилу, била је уведена делимична или потпуна забрана кретања за одређене категорије људи, са временским трајањем ове мере. Постојала је обавеза држања дистанце међу људима, као и избегавање било какве врсте физичког контакта. Било је забрањено јавно окупљање грађана на отвореним или затвореним просторима или лимитиран њихов број. Приватне прославе су такође биле забрањене. Компаније су делимично или потпуно прекинуле рад и прешло се на рад од куће, путем интернета, где је год то због природе посла било могуће. Спортски догађаји и културне менифестације су отказани у (готово) свим државама Европе. Образовни системи су заустављени на

65 ...Коментаришући нову (лидерску) позицију Кине у области економских односа држава, Меркелова је констатовала да „пример Кине показује да чак и недемократска држава може бити економски успешна, што је велики изазов за наше (западне - прим. аут.) либералне демократије“. Видети детаљније: Ибид.

66 Ибид. 
свим нивоима: од основних школа до факултета. Са редовне наставе прешло се на наставу путем интернета. Јавни превоз је редукован, а на појединим линијама и потпуно обустављен. Здравствени системи су због потребе заштите њихових капацитета реорганизовани. Борба против вируса ковид 19 је била приоритет свих држава. Са попуштањем епидемије, тј. смањењем броја особа заражених ковидом 19, државе су доносиле нове мере. Ванредно стање је поново уведено само у окрузима или градовима где је регистрован велики број новозаражених лица. У осталом делу земље поново је покренута производња, отворени угоститељски и др. јавни објекти, наравно, уз поштовање мера социјалне дистанце (одстојања) међу људима и примену хигијенских мера. Спољне границе држава су отворене, али не безусловно. Страни држављани су могли ући на територију дате државе уз лекарски доказ да нису заражени вирусом ковид 19 или уз обавезан боравак у карантину у периоду од две недеље. Унутар Европске уније за грађане држава чланица било је дозвољено слободно кретање. Али према трећим земљама били су постављени посебни услови уласка. Саме државе су поново утврђивале критеријуме ко је могао слободно ући и боравити у њиховој земљи или, уколико је у транзиту, у ком временском року се мора „проћи“ кроз државу.

Државе су се показале као најважнија и најефикаснија карика у спречавању ширења вируса и санирању његових последица67. Свака држава је потпуно аутономно доносила одговарајуће мере. То „богатство различитости“ деловања држава у борби против ковида 19 врло брзо се исказала и између држава чланица ЕУ. За разлику од ранијих изазова са којима се суочавала ЕУ, где је јединствено деловање свих чланица апострофирано као главни квалитет и вредност ЕУ, а слободно кретање „део европског начина живота и предуслов за функционисање европског тржишта“68, сада је заједничка политика „нестала“, а кретање људи заустављено у корист појединачних мера држава̂. Због различите здравствене ситуације државе су доносиле одлуке (мере) искључиво у складу са својом проценом (интересима). Тако је било и приликом затварања и отварања граница. Шведска и Луксембург су, примера ради, своје границе држале отвореним цело време трајања пандемије. Аустрија је на своју листу забране држава чијим грађанима није дозвољено да уђу ставила Вел. Британију, Шведску, Шпанију, Португалију, али и покрајину Ломбардију из Италије, где је био највећи број

67 Видети детаљније: Ивана Шундић Миховиловић, „Гранцие најефикасније средство против вируса“, Данас, 5. мај 2020, https://www.danas.rs/svet/granice-najefikasnijesredstvo-protiv-virusa/, 05/05/2020; Љиљана, Бегенишић, „Историчар др Милош Ковић: Ковид 19 показао да само националне државе могу да заштите грађане“, Новости, 30. април 2020, https://www.novosti.rs/vesti/naslovna/drustvo/aktuelno.290.html:862131Istoricar-dr-Milos-Kovic-Kovid-19-pokazao-da-samo-nacionalne-drzave-mogu-da-zastitegradjane, 30/04/2020.

68 „DW: Границе ЕУ се поново отварају“, Б92, 14. мај 2020, https://www.b92.net/info/vesti/index.php?yyyy=2020\&mm=05\&dd=14\&nav_category=78\& nav_id=1683887, 14/05/2020. 
заражених и преминулих особа од ковида 19. Неке државе су примениле реципроцитет, нпр. Француска за Вел. Британију и Ирску. Другима је економски интерес (туризам) био критеријум пријема. Шпанија је била забранила улазак држављана других држава до 1. јула, са изузетком неколико десетина хиљада немачких туриста. Данска је такође дозволила улазак туристима, али само из Немачке, Норвешке и Исланда69. За улазак у простор држава чланица ЕУ грађана из трећих земаља утврђена су посебна правила. О тим условима (правилима уласка) одлучивале су саме државе. Тако је списак од 15 држава којима је ЕУ дозволила улазак на просторе држава чланица од 1 јула у пракси постао далеко мањи ${ }^{70}$. Свака држава је имала посебне услове које је било потребно испунити да би се могло ући на њену територију (епидемиолошка ситуација у земљи доласка не старија од 72 сата, стопа заражености становника и др.). И земље ван простора ЕУ су имале исти приступ (своје критеријуме) приликом одлучивања ко може ући на њену територију. Колико субјективног (политичког) има у одређивању услова, најбоље се могло видети у одлуци Црне Горе да не дозволи слободан улазак грађанима Србије, чак ни са негативним тестом на корону, образлажући своју одлуку епидемиолошким параметрима у Србији, и то у исто време када је ЕУ препоручила својим чланицама да грађанима Србије омогући улазак на територије држава чланица ${ }^{71}$.

Крајем јуна, без обзира на чињеницу да је Европска унија дозволила прелазак границе међу државама чланицама, грађанима Шведске није дозвољено да уђу у суседне земље: Норвешку, Данску и Финску72. Разлог томе је био висок број заражених и умрлих особа од последица ковида 19 у Шведској ${ }^{73}$.

69 ...Наведено према: Горан, Чворовић: „Све више рампи кроз отворену Европску унију: Нико не зна шта га чека ако крене на пут“, Новости, 16. јун 2020, https://www.novosti.rs/vesti/planeta.299.html:870883-Sve-vise-rampi-kroz-otvorenu--

Evropsku-uniju-Niko-ne-zna-sta-ga-ceka-ako-krene-na-put, 16/06/2020.

70 На списку земаља за које је Европска унија отворила своје спољне границе од 1 јула налазиле су се: Алжир, Аустралија, Канада, Грузија, Јапан, Црна Гора, Мароко, Нови Зеланд, Руанда, Србија, Јужна Кореја, Тајланд, Тунис, Уругвај и Кина (под условом да Кина дозволи улазак грађана, чланица ЕУ). Наведено према: Никола, Радишић, „Грађани Србије од 1. јула могу у Европску унију“, N1, 30. јун 2020,

http://rs.n1info.com/Vesti/a615052/Evropska-unija-od-1.-jula-otvara-granice-za-gradjaneSrbije.html, 30/06/2020.

71 Видети детаљније: „Црна Гора отвара границе за ЕУ, са Србијом остаје затворена“, N1, 30. јун 2020, http://rs.n1info.com/Region/a615144/Crna-Gora-otvara-granicu-sa-EU-saSrbijom-ostaje-zatvorena.html, 30/06/2020; „Очекује се да Црна Гора измени одлуку о забрани уласка“, Политика, 3. јун 2020, стр. 5.

72 Видети детаљније: „Швеђанима забрањен улаз у Норвешку, Финску и Данску“, Политика, 24. јун 2020, стр. 3.

73 Шведски модел борбе против ковида 19 (либерални приступ без рестриквитних мера), од кога се очекивало да ће довести до стицања имунитета крда и тако зауставити вирус, по мишљењу тима од 25 шведских лекара и научника није успео. Против оваквог приступа борби против короне, тј. стратегије имунитета крда била је и Светска здравствена организација. Шведска има велики број случајева заражених од 
Исто се десило и са грађанима Србије. Иако се Србија налазила на списку од 15 држава чији су грађани могли да уђу на територије држава чланица ЕУ, погоршање епидемиолошке ситуације у Србији изазвало је реакцију чланица ЕУ затварање својих граница. Најпре једна, а онда готово све чланице ЕУ су затвориле своје границе за грађане Србије.

Како се мењала ситуација у вези са новим вирусом, државе су мењале своју стратегију и доносиле нове мере. Неке државе су одустале од ванредног стања на нивоу целе државе и усмериле се на заустављање ширења ковида 19 у постојећим жариштима. У Јужној Кореји власти су поред тестирања и праћења људи (мера које су у почетку дале одличне резултате), са новим ширењем вируса затвориле јавне установе на две недеље, а путници у јавном превозу су имали обавезу да користе маске. У Јапану је покренута апликација за праћење контаката, која обавештава кориснике о присуству особа̂ које су заражене у последње две недеље. У Немачкој је прописано да општине и региони који имају више од 50 нових заражених особа на 100.000 становника, морају да затворе школе, организују карантине и масовно тестирање. У Кини током борбе против ковида 19 било је практично „затворено“ више градова и области у којима је живело више стотина милиона људи. Вухан, град у ком се нови вирус појавио, био је у строгој изолацији од краја јануара, а тек почетком маја су укинута последња ограничења. Када је 12 јуна објављено да је у Пекингу заражено 53 особе, власти су одмах затвориле пијацу са које је све потекло, као и део града око пијаце у ком је живело 2,3 милиона људи. На тестирању становника овог дела Пекинга ангажовано је 100.000 радника74.

Ширење коронавируса унутар држава изазвало је огроман „притисак“ заражених особа на здравствене системе држава. Показало се да највећи број држава у условима наглог прилива великог броја оболелих од ковида 19 нема ни одговарајући (потребан) здравствени простор, нити довољно потребне медицинске опреме и лекова: заштитне маске и одела, боце са кисеоником, респираторе, различите врсте лекова, дезинфекциона средства и др. Због тога многе болнице у државама са високим нивоом здравствене заштите, са бројном опремом, нису биле у могућности да пруже потребну медицинску негу и помоћ свим пристиглим пацијентима зараженим од ковида 19. У болницама на северу Италије, као и у граду Њујорку (у Сједињеним Америчким Државама), због пренатрпаности простора новозараженим особама пацијенти су једног тренутка били смештени у ходницима болница, где су примали терапију. Појавио се и проблем недостатка респиратора у болницама, што је

коронавируса и велики број преминулих особа. У Шведској је „број умрлих већи него у Америци: тамо је 20. јула забележено 556 смртних случајева на милион становника, а у САД 425“. Наведено према: „Научници се слажу: Шведски приступ борби против ковида 19 није успео“, Новости, 24. јул 2020, https://www.novosti.rs/c/planeta/svet/9044475/naucnici-slazu-svedski-pristup-borbiprotiv-kovida-19-nije-uspeo, 24/07/2020.

74 Наведено према: „Државе користе различите стратегије, правила нема“, Недељник, бр. 58, јул 2020, стр. 4. 
борбу против пандемије учинило још тежом и трагичнијом. Ситуација у бројним другим мање развијеним државама, где је такође био велики број људи заражених новим вирусом, била је много гора.

Последица пандемије свакако је и јачање улоге државе и на унутрашњем и на међународном плану. Суочавање са ковидом 19 је код многих држава отворило питање начина организације здравственог система и могућности сопственог осигурања потребне медицинске опреме и лекова, пре свега, а затим и бројна друга питања: од структуре националних економија и степена економске зависности од других држава, начина и организације деловања државе у ванредним случајевима (пандемији вируса), и то не само државна управа, већ и образовање и др. области живота. Јаче и јасније него икад пре у последњих неколико деценија отворено је питање националне и економске сигурности држава.

\section{ПОСЛЕДИЦЕ У ОБЛАСТИ ЕКОНОМИЈЕ}

Пандемија ковида 19 је поред питања стања светске економије и последица по националне економије држава отворила и питање могућности функционисања постојећег модела „економске сарадње“ на глобалном плану, али и питање економске безбедности држава. Заустављањем кретања људи, робе и капитала прекинута је привредна сарадња, размена производа, ланац снабдевања. Кретање вируса од истока према западу, из Кине у друге државе света, али пре свега мере које су државе предузеле у сузбијању ковида 19 и опоравку и јачању националних економија, имали су за последицу и пораст или пад економских активности држава, а тиме и њихове економске моћи на међународном плану.

Пандемија је утицала негативно и на стање економије на светском нивоу, а поготову унутар држава које су свој економски развој везале за међународну сарадњу. Међународни монетарни фонд је у периоду априла и маја проценио да ће због корона кризе светска економија „вероватно доживети најдубљи колапс од велике кризе 1930-их“75. Пројекција кретања економских активности и на глобалном плану и у земљама појединачно за текућу годину била је негативна, а за 2021. год. је зависила од дужине трајања короне76. Сабирајући економске и финансијске последице коронавируса на глобалном плану од априла до јуна ММФ је крајем јуна изашао са још лошијим проценама: да ће пад економских активности бити око 5\% (у односу на три посто у априлу). Привредни пад ће бити у свим земљама већи него што се веровало у априлу.

\footnotetext{
75 Наведено према: Марко, Андрејић и Тања, Ковачевић, „59 милиона Европљана без посла, масовни банкроти, рецесија: Корона је светској економији ударила незапамћен шамар, шта је следеће: најцрњи сценарио или преокрет“, Блиц, 2. мај 2020, https://www.blic.rs/biznis/privreda-i-finansije/59-miliona-evropljana-bez-posla-masivnibankroti-recesija-korona-je-svetskoj/fj0n7lp, 24/07/2020.

76 Наведено према: Ибид.
} 
Са проблемима у пословању су се суочиле и највеће мултинационалне компаније. Према подацима организације Уједињених нација - UNCTAD - 42 од 100 највећих компанија су имале проблеме са пословањем. То ће без сумње утицати и на умањење планираних инвестиција, на плате запослених, што ће опет утицати на смањење потрошње, као и на економију у целини ${ }^{77}$. Проблеми мултинационалних компанија су се „прелили“ на бројне државе у којима су оне имале своја предузећа, посебно земље у развоју, чији је утицај на развоју планете био значајан ${ }^{78}$. Стране инвестиције су успорене или потпуно обустављене. Капитал је, вођен логиком профита и интересима власника, брзо напустио одређене земље ${ }^{79}$. Унутар самих земаља у развоју бројне гране привреде које су зависиле од размене производа и кретања људи нашле су се на ивици опстанка. Државе које су извозиле различите врсте руда (сировина) морале су да смање или обуставе производњу, јер је извоз стао, а цена тих руда на светском тржишту су пале. У истој или сличној ситуацији су се нашле земље које производе бакар (Чиле, Перу, Демократска Република Конго или Замбија), цинк (Бразил и Индија), извозници нафте (Колумбија, Алжир, Мозамбик, Ирак и Нигерија) и др. ${ }^{80}$

Ни богате, економски развијене земље нису биле изузете од негативних последица ширења вируса ковид 19. Међу развијеним државама пад ће бити највећи у економијама Француске, Велике Британије, Шпаније и Италије. И америчку привреду, према процени ММФ-а, такође чека пад. Процене Светске банке и ОЕЦД-а биле су још лошије. Рачуница ММФ-а за НР Кину, другу економију света, била је другачија. Кина би требало да у 2020. години забележи привредни раст од $1 \%$ (годину дана раније раст је био око $6 \%)^{81}$.

Криза изазвана пандемијом представља претњу и за запослене. Процене последица пандемије указују да је у опасности 59 милиона радних места у ЕУ и Великој Британији. Нико од запослених није поштеђен могућег отказа, а у неким

77 Наведено према: Ибид.

78, Према подацима Међународног монетарног фонда...,ТТжишта земаља у развоју чине 60 посто светске економије по куповној моћи. Спорије развијање ових тржишта значи спорије развијање читаве планете“, Видети детаљније: „Како ће земље у развоју преживети?“, Недељник, бр. 55, април 2020, стр. 4.

79 Према подацима Института за међународне финансије, до 2019. године тржишта Кине, Индије, Јужне Африке и Бразила „имала су нето инвестиције од 79 милијарди долара“. Услед пандемије „за само два месеца више од 70 милијарди долара изашло је из тих земаља. Неке би могле да прогласе банкрот - пре свих Аргентина, Турска и Јужна Африка“. Наведено према: Ибид, стр. 4.

80 Видети детаљније: Ибид. стр. 4.

81 Сви подаци наведени према: Тања, Вујић „ММФ: Криза какву свет није видео“, Политика, 27. јун 2020. http://www.politika.rs/scc/clanak/457157/MMF-Kriza-kakvu-svet-nije-video, $28 / 06 / 2020$. 
гранама, као што су нпр. угоститељство и туристички смештај, чак три од четири запослена могу остати без посла ${ }^{82}$.

Негативне последице ковида 19 по своју економију државе су покушале да поправе различитим врстама економске помоћи - од доделе бесповратних средстава, кредита, олакшица код плаћања пореза, новчаних и надокнада за запослене и др. Држава се супротно логици либералног капитализма, где тржиште аутономно регулише привредну активност компанија (па тиме и њихову судбину, укључујући и запослене), овог пута појавила као регулатор и заштитник привредног система земље. Наравно, домашај ових мера зависио је првенствено од економских могућности (стања буџета) сваке земље. Немачка је, примера ради, одлучила да „домаћој привреди погођеној короном стави на располагање 130 милијарди евра до краја 2021.“83 Средства су намењена за подстицај производње у различитим гранама привреде ${ }^{84}$. Сједињене Америчке Државе су крајем марта за заштиту економије одобриле „пакет“ економске помоћи од 2.000 милијарди долара и већ размишљају о могућности усвајања новог пакета помоћи.

НР Кина се прва суочила са ковидом 19 и његовим последицама. Као добро организована и ефикасна држава, уз дисциплину људи у поштовању мера против вируса и уз примену економских мера за санирање последица прекида производње због ковида 19 и њеног подстицаја, Кина је била прва земља која је обновила производњу и покренула замајац развоја. Друге земље су се тек суочавале са ковидом 19 и последицама његовог ширења. О мерама подршке економији тек се разговарало. У Европској унији је то било утолико теже, јер су чланице биле различито погођене новим вирусом, постојала је разлика у економској снази међу њима, па су логично и „погледи“ како обновити производњу и које мере применити за развој економије биле различите. Такав развој догађаја довео је НР Кину у позицију „стратешке предности“ у односу на друге економије света, посебно у односу на Сједињене Америчке Државе. Свет је „одједанпут“ изгледао другачије него шест месеци пре него се појавио вирус ковид 19. Кина се појавила на светској сцени као нова економска суперсила. Може се закључити да досадашњи концепт односа, „идеја светске економије којој председава Америка се распада, а фактори су и узлет Кине и окретање Сједињених Држава ка национализму“85.

82 Наведено према: Марко Андрејић и Тања Ковачевић, „59 милиона Европљана без посла, масовни банкроти, рецесија: Корона је светској економији ударила незапамћен шамар, шта је следеће: најцрњи сценарио или преокрет“, op. cit.

83 Наведено према: Тања Вујић, „Меркелино „најн“ и Америци и Кини“, Политика, бр. 38270, 2020, стр. 3.

84 ..,У пакету стимулативних мера Берлин је истакао развој сопствене 5Г мреже (терен на којем се глобално шири Кинески „Хуавеј“) и подстицаје за куповину електричних аутомобила“. Видети детаљније: Ибид, стр. 3.

85 Наведено према: „Ово је крај економије какву смо знали“, Недељник, бр. 56, мај 2020, стр. 9. 
Пандемија је са свим својим негативним последицама у друштву и економији највећег броја држава (прекид кретања људи и роба, затварање саобраћаја, пад производње у економији, велики број људи који су добили отказе или им је угрожено радно место, уз јачање улоге државе у решавању насталих проблема: од здравствених и економских пре свега, а потом и свих осталих и др.) - отворила питање опстанка либералног модела организације друштва и постојећег поретка односа моћи међу државама. Многи научници оцењују да је „постало очигледно да либерални капитализам не ради“ и да „и они који у добрим временима не верују у државу, траже неку помоћ“86. Промене у свету изазване ковидом 19 су већ почеле. Француски лист Монд је оценио да „светска здравствена криза због короне вируса дубински мења односе међу великим силама“, да „међународни поредак изграђен под вођством САД после Другог светског рата више није прилагођен стварности односа снага у 21. веку“ и да је „моћ Кине уздрмала цео систем“87. Да су промене постојећег светског поретка у току и да је време доминације САД прошло, потврђују и амерички експерти који су говорили за Forin afers; они закључују да Америка, уколико не жели да се „нађе међу губитницима у борби за нови међународни поредак“, треба да призна „да свет више не подсећа на епоху деведесетих година прошлог века и прве деценије овог века"88. Да се актуелни светски поредак налази у „фази промене“, потврђује и познати научник Ф. Фукујама (који је иначе сматрао да је модел друштва либералне демократије супериорнији у односу на све друге), који тврди да „период у којем смо се нашли подсећа све да је државна моћ и даље веома важна, и по свему судећи представља посмртно звоно добу неолиберализма, које је започело са Реганом и Тачеровом осамдесетих година“89.

86 Наведено према: Душан Стојаковић, „Јоже Менцингер: Надам се да је корона крај либералног капитализма, сада и они који не верују у државу од ње траже помоћ“, Новости, 1. мај 2020,

https://www.novosti.rs/vesti/naslovna/ekonomija/aktuelno.239.html:862160-Joze-

Mencinger-Nadam-se-da-je-korona-kraj-liberalnog-kapitalizma-sada-i-oni-koji-ne-veruju-udrzavu-od-nje-traze-pomoc, 01/05/2020.

87 Наведено према: „Моћ Кине је уздрмала цео систем“ ‘Монд` без длаке на језику о ЕУ, УН, здравственој кризи: Америка више није вођа света!“, Курир, 1. мај .2020, https://www.kurir.rs/planeta/3456705/moc-kine-je-uzdrmala-ceo-sistem-mond-bez-dlakena-jeziku-o-eu-un-zdravstvenoj-krizi-amerika-vise-nije-vodja-sveta, 02/05/2020; Борис Над, „Америка против Кине: Да ли је „тачка неповрата“ већ пређена“, Печат, бр. 615, 15. мај 2020, http://www.pecat.co.rs/2020/05/da-li-je-tacka-nepovrata-vec-predjena/, 15/05/2020.

88 Наведено према: „Амерички експерти: Америка изједа саму себе, време њене доминације је прошло“, Нови стандард, 02. јул 2020, https://www.standard.rs/2020/07/02/americki-eksperti-amerika-izjeda-samu-sebe-vremenjene-dominacije-je-proslo/, 25/07/2020.

89 Наведено према: Вељко Лалић, „Франсис Фукујама ексклузивно за Недељник: Неолиберализму је одзвонило“, Недељник, 12. април 2020, https://www.nedeljnik.rs/fransis-fukujama-ekskluzivno-za-nedeljnik-neoliberalizmu-jeodzvonilo/, 13/04/2020. 
Заустављањем саобраћаја и кретања људи међу државама (и на глобалном и на регионалном нивоу) највише су поред мултинационалних компанија које су имале своја предузећа у више држава света биле погођене државе у чијој је економији туризам имао веома важно место. А Италија свакако јесте једна од таквих држава. У 2018. години туризам је учествовао са 13,2\% у бруто друштвеном производу земље, односно са 232 милијарде евра. Године 2019. више од 63 милиона људи је путовало у Италију, што је било за 2,3\% више него годину дана пре. Ковид 19 је зауставио путовања и кретање људи. Туриста у Италији нема, или их има спорадично у односу на очекивања и ранија времена. Прогнозе предвиђају пад од 72,9\% мање путника из Сједињених Америчких Држава у периоду од маја до октобра. Удружење италијанских хотелијера је објавило да је у априлу био пад од 99,1\% међу страним гостима у односу на април 2019. године. Друго удружење хотелијера је објавило да је хотелска индустрија у периоду од 1. марта до 31. маја изгубила 11 милијарди евра. Последице овакве ситуације биће разарајуће по туризам и економију земље. У Италији око 3,5 милиона људи директно зависи од туризма (особље ресторана, хотелијери, туристички водичи, организатори туристичких путовања, таксисти и други). Влада је као привремену меру одређеним категоријама радника у туризму (нпр. радницима без уговора и др.) гарантовала по 600 евра за март и април. Синдикат туристичких водича тражи да се исплата 600 евра настави до марта 2021. године, јер посла нема90. Али није само Италија у области туризма била велики губитник због пандемије. И афричке зеље су изгубиле због пандемије „готово 55 милијарди долара прихода у индустрији путовања и туризма “91.

Још једна привредна грана држава̂, поготову развијенијих, била је јако погођена проглашењем пандемије коронавируса. То је авиоиндустрија. Прекид ваздушног саобраћаја широм света није значио само прекид путовања људи или транспорт роба међу државама. Међу авиокомпанијама је отворено питање коришћења појединих типова авиона, поготову оних највећих, и то због потребе смањења „трошкова и ресурса“ (нпр. двоспратних авиона Ербас или Боинг, који могу да приме неколико стотина, тј. највећи број путника). Смањена је такође и потреба за услужним делатностима различите врсте техничког и другог особља, које је практично остало без посла. Мали број летова је условио смањење или отказивање набавке нових авиона, чиме је највише погођена индустрија производње авиона. Мањи бој летова аутоматски је значио и мање потребе за пилотима и другим члановима кабинетског особља и др. Међународно удружење за ваздушни превоз (ИАТА) је објавило да „се авиосаобраћај неће вратити на ниво пре епидемије коронавируса до 2023. године (подвукао Ж.О.), као и то да ће следеће године саобраћај бити 24 одсто смањен у односу на период пре

\footnotetext{
90 Наведено према: „Паралисан италијански туризам“, Недељник, бр. 58, јул 2020, стр. 5.

91 Изјава комесарке Афричке уније за инфраструктуру и енергетику, Амани Абоу Зеид, Видети детаљније: „Трамп верује да ће САД ускоро имати вакцину; нове мере на снази у Црној Гори“, ор. cit.
} 
пандемије“92. Као последица овакве ситуације, која ће трајати годинама, велике авиокомпаније су најавиле смањење броја запослених. Једна од највећих светских авиокомпанија Емирејт „разматра отпуштање чак 30.000 људи“93. Постало је јасно да многе авиокомпаније неће „преживети“ пандемију вируса, сем уколико не обезбеде потребну финансијску помоћ „својих“ држава94. А та финансијска помоћ је објективно лимитирана због негативних последица пандемије на укупну економију држава.

Пандемија ће без сумње утицати на промене економије великог броја држава, нарочито развијених. Доћи ће до повећања коришћења нумеричких технологија, роботизације у индустрији, а рад на даљину ће променити начин функционисања свих запослених 95 .

\section{БОРБА ПРОТИВ ДЕЗИНФОРМАЦИЈА}

Вирус ковид 19 је на међународном плану постао предмет пропагандног рата појединих држава и појединаца, уз истовремено промовисање различитих квазинаучних теорија о начину његовог настанка, ширења и последицама. Тврдњу да нови вирус није природног порекла, већ да је настао у кинеској лабораторији у Вухану и да представља биолошко оружје, заступали су бројни научници, лекари, али и представници држава. Док се за ставове појединаца може прихватити као одраз нивоа знања о ковиду 19, кад је реч о представницима држава, поготову САД, и то у односу на Кину, онда се не могу пренебрегнути директне политичке, односно међудржавне димензије. Оптужбама против Кине желела се скренути пажња јавности са дешавања унутар САД у борби против ковида 19, великог броја заражених и нажалост преминулих особа, питања оспособљености државе да се савлада нови вирус и наравно стања здравственог система земље. Други разлог критика упућених Кини лежи у самом односу који САД имају према Кини. За њих је Кина, као велика и моћна држава, не само противник и претња за глобално лидерство, већ и дежурни кривац за све. Чињеница да се нови вирус појавио у Кини давала је упућеним критикама

92 Наведено према: „Авиогигант отпушта чак 30.000 запослених?“, Б92, 18. мај 2020, https://www.b92.net/biz/vesti/svet.php?yyyy=2020\&mm=05\&dd=18\&nav_id=1685026, $18 / 05 / 2020$.

93 ...Наведено према: Исто.

94 Наведено према: „Аустрија уводи контроверзне промене: Веће таксе и одређивање минималне цене авионских карата“, Б 92, 10. јун 2020.

https://www.b92.net/biz/vesti/svet.php?yyyy=2020\&mm=06\&dd=09\&nav_id=1693251, $18 / 05 / 2020$

95 Наведено према: „Лагард: Пандемија ће убрзати трансформацију европских економија“, РТC, 4. јул 2020,

https://www.rts.rs/page/stories/ci/\%D0\%9A\%D0\%BE\%D1\%80\%D0\%BE\%D0\%BD\%D0\%B 0\%D0\%B2\%D0\%B8\%D1\%80\%D1\%83\%D1\%81/story/3175/ekonomija-i-

epidemija/4008583/lagard-pandemija-ekonomija.html, 04/07/2020. 
додатну тежину. Медији су такође преносили и бројне информације да је 5Г технологија узрочник настанка и ширења ковида 19. Колико су овакве тврдње опасне, показује и случај из Велике Британије, где су присталице ове теорије „палили предајнике и претили радницима телекомуникационих компанија“96. Научни деманти таквих тврдњи изнетих од стране релевантних међународних институција, као што је Међународна комисија за заштиту од нејонизирајућег зрачења, коју признаје Светска здравствена организација - нису зауставили ширење ових информација.

Најприсутнија појава оспоравања опасности ширења и последица вируса ковид 19 огледа се у готово перманентном промовисању ставова да „пандемије заправо и нема“, „да се последице вируса преувеличавају“, „да је посреди лажна узбуна грађана од стране државе и са намером контроле њиховог кретања и понашања“, „да подаци о броју заражених и преминулих лица нису тачни“, већ се повећавају и смањују у складу са стратегијом владајућих политичких снага појединих држава. Ови ставови су здушно подржани, не само од стране појединих здравствених радника, већ и научника, припадника невладиних организација, државних органа, па чак и представника националних парламената.

Поменутим теоријама треба додати и ону која ширење опасности утицаја вируса на здравље грађана приписује плану уског круга људи који зарад личних или интереса фармацеутских компанија указују на нужност коришћења вакцина (којих још увек нема) као једног сигурног начина борбе против ковида 1997.

Пандемија ковида 19 траје. Број заражених и преминулих од новог вируса константно расте. Вирус се по мишљењу лекара код заражених особа испољава кроз нове симптоме, што присталицама различитих ненаучних теорија представља основ за деловање. То борбу држава̂ против ковида 19 чини тежом и комплекснијом, не само према оболелим особама већ и према целом друштву, у пружању релевантних информација грађанима како се супротставити ширењу заразе, али и у сузбијању нетачних и непроверених информација.

\section{ЗАКљУЧАК ${ }^{98}$}

Пандемија вируса ковид 19 је на глобалном плану изазвала неколико за будућност човечанства важних последица. Заустављањем кретања људи и роба прекинут је ланац снабдевања међу државама и рад бројних компанија,

\footnotetext{
96 Видети детаљније: Јелена Каваја, „Стари митови оживели у новој верзији“, op. cit.

97 Видети детаљније: Данијела Давидов-Кесар, „Зараза која не престаје“, Политика, 18. мај 2020, http://www.politika.rs/scc/clanak/454299/Zaraza-koja-ne-prestaje, 18/05/2020; Александар Апостоловски, „Биле, ковидов сине“, Политика, 19. мај 2020, http://www.politika.rs/scc/clanak/454439/\%D0\%91\%D0\%B8\%D0\%BB\%D0\%B5\%D0\%BA\%D0\%BE\%D0\%B2\%D0\%B8\%D0\%B4\%D0\%BE\%D0\%B2\%D1\%81\%D0\%B8\%D0\%BD\%D0\%B5, 19/05/2020.

98 Аутор је при изради овог рада, анализи последица вируса ковид 19 на глобалном плану, обухватио период од појаве новог вируса, почетком јануара до краја јула 2020. године.
} 
укључујући и оне које су имале своје огранке у различитим државама света. Процес глобализације је заустављен, а њена „структура и брзина су промењени“. Бројне државе су се суочиле са падом производње и другим проблемима у економији. Уместо тржишта, као регулатора економских активности, ојачала је улогу државе, која је својим мерама подршке компанијама и запосленима ублажила негативне последице пандемије у економији, ојачала предузећа, створила услове за производњу и међудржавну сарадњу. Таква улога државе отворила је и питање судбине либералног модела економске организације друштва, тј. да ли је либерални систем исцрпао своје могућности и да ли се још увек може сматрати доминантним у светским размерама. Вирус ковид 19 је „допринео“ и променама у односима глобалне моћи међу водећим државама. НР Кина уместо Сједињених Америчких Држава у време пандемије постаје водећа држава света.

Држава је поново постала центар дешавања на унутрашњем плану и у међународним односима. Начелне одлуке међународних организација и заједница држава са глобалног и регионалног нивоа су остављене на тумачење и примену државама појединачно. Свака држава је настојала да заштити прво себе (своје грађане), па тек онда да буде део неке заједничке одлуке. Поједине државе у борби против ковида 19 су се показале себичним, неспремним да своје економске и медицинске ресурсе и знање поделе са другим. Државе су доносиле одлуке о увођењу ванредног стања, али и све друге мере за заустављање ширења ковида 19. Одлуке о затварању или отварању својих граница за улазак држављана других држава, али и унутар земље о стављању одређених области у карантин, такође су биле аутономна ствар држава. Поред тога, државе су доносиле економске мере подршке компанијама, како би сачувале привредни систем земље. Економска помоћ грађанима коју су давале поједине државе (не све), такође је била у функцији санирања последица коронавируса.

Упркос великим напорима држава у сарадњи са Светском здравственом организацијом у сузбијању ширења ковида 19 и отклањању његових последица, пандемија још увек није завршена. Напротив, број заражених и преминулих људи од новог вируса се свакодневно повећава. Предузете мере нису још увек зауставиле вирус. Крајем јула преко 16 милиона људи је било заражено коронавирусом99. Борба држава против ковида 19 наставља се и неспорно је да ће државе и народи бити суочени са новим изазовима.

Пандемија ковида 19 је указала на једну важну чињеницу савременог света. Иако је пандемија на одређени начин „затворила“ свет, она је са друге стране указала на који начин се може победити вирус ковид 19, али и сваки следећи. То је међусобна сарадња држава, размена података, искустава и рад на заједничким истраживањима. Свету је потребна вакцина против ковида 19, и то што пре.

99 Наведено према: „Директор СЗО упозорава: Нисмо ни близу краја, пандемија се убрзава!“, Новости, 29. јун 2020, http://www.novosti.rs/vesti/planeta.299.html:873312Direktor-SZO-upozorava-Nismo-ni-blizu-kraja-pandemija-se-ubrzava, 29/06/2020. 
Велике, економски јаке земље, самостално или у сарадњи са другим државама, раде на проналажењу нове вакцине. То је дуг, научно и технички тежак пут, који захтева више истраживања, проба, примена, поштовање протокола, одобрења, сагледавање нежељених ефеката, па тек онда добијање коначних дозвола за масовну примену. Зато је важна сарадња држава и њихових истраживачких лабораторија, јер се разменом информација скраћује временски период за проналазак и примену нове вакцине, што је свету потребно.

\section{ЛИТЕРАТУРА}

- „15.000.000“, Б92, 21. јул 2020.

https://www.b92.net/info/vesi/index.php?yyyy=2020\&mm=07\&dd=21\&nav_catego ry=78\&nav_id=1709563.

- „COVID19 Coronavirus pandemic”, Worldometer, https://www.worldometers.info/coronavirus/.

- „DW: Границе EУ се поново отварају“, Б92, 14. мај 2020. https://www.b92.net/info/vesti/index.php?yyyy=2020\&mm=05\&dd=14\&nav_categ ory=78\&nav_id $=1683887$.

- „Авиогигант отпушта чак 30.000 запослених?“, Б92, 18. мај 2020. https://www.b92.net/biz/vesti/svet.php?yyyy=2020\&mm=05\&dd=18\&nav_id=168 5026.

- „Америка је направила две фаталне грешке са короном; доктори вичу: 'Ово је ужас`, а Трамп одговара: Не шалим се!“, Блиц, 20. јул .2020, https://blic.rs/vesti/svet/amerika-je-napravila-dve-fatalne-greške-sa-koronomvirusom-doktori-vicu-ovo-je-uzas.a-tramp/619gsw9.

- „Амерички експерти: Америка изједа саму себе, време њене доминације је прошло“, Нови стандард, 2. https://www.standard.rs/2020/07/02/americki-eksperti-amerika-izjeda-samusebe-vreme-njene-dominacije-je-proslo/.

- „Аустрија уводи контроверзне промене: Веће таксе и одређивање минималне цене авионских карата“, Б92, 10.2020 , https://www.b92.net/biz/vesti/svet.php?yyyy=2020\&mm=06\&dd=09\&nav_id=169 3251.

- „Баснословни договор Европске уније уз папрене уступке“, „Господин „не“ против Меркелове и Макрона“, Политика, 22. јул 2020.

- „Борељ: Извоз медицинске опреме на Западни Балкан, без посебних дозвола“, $\begin{array}{llll}\text { PTC, } & 20 . & \text { април } & 2020 .\end{array}$ https://www.rts.rs/page/stories/sr/\%D0\%9A\%D0\%BE\%D1\%80\%D0\%BE\%D0\%B D\%D0\%B0\%D0\%B2\%D0\%B8\%D1\%80\%D1\%83\%D1\%81/story/3138/koronaviru s-u-svetu/3928745/borelj-eu-zapadni-balkan-oprema-izvoz-.html.

- „Брисел: ЕУ у историјској рецесији“, Политика, 8. мај 2020. 
- „Демократе и републиканци договорили пакет помоћи вредан 2.000 милијарди долара“, N1, 25. март 2020, http://rs.n1info.com/Biznis/a581700/Paket-pomoci-uSAD-za-saniranje-posledica-koronavirusa.html.

- „Директор СЗО упозорава: Нисмо ни близу краја, пандемија се убрзава!“, Новости, 29. јун 2020, http://www.novosti.rs/vesti/planeta.299.html:873312Direktor-SZO-upozorava-Nismo-ni-blizu-kraja-pandemija-se-ubrzava.

- „Директор СЗО: Корона вирус је десет пута смртоноснији од свињског грипа“, $\begin{array}{llll}\text { PTC, } & 14 . & \text { април } & \end{array}$ https://www.rts.rs/page/stories/sr/\%D0\%9A\%D0\%BE\%D1\%80\%D0\%BE\%D0\%B D\%D0\%B0\%D0\%B2\%D0\%B8\%D1\%80\%D1\%83\%D1\%81/story/3138/koronaviru s-u-svetu/3922211/szo-gebrejesus-koronavirus.html.

- „Државе користе различите стратегије, правила нема“, Недељник, бр. 58, јул 2020.

- „ЕУ и САД бележе историјски привредни пад“, РТС, 30. април 2020. https://www.rts.rs/page/stories/ci/\%D0\%9A\%D0\%BE\%D1\%80\%D0\%BE\%D0\%B D\%D0\%B0\%D0\%B2\%D0\%B8\%D1\%80\%D1\%83\%D1\%81/story/3175/ekonomijai-epidemija/3939477/sad-eu-privredni-pad-korona.html.

- „ЕУ јасно ставила до знања на чијој је страни: Преиспитајте одлуку“ Б92, 30. мај 2020,

https://www.b92.net/info/vesti/index.php?yyyy=2020\&mm=05\&dd=30\&nav_categ ory=78\&nav_id $=1689672$.

- „ЕУ, Немачка и Кина осудиле одлуку САД да у јеку пандемије обуставе финансирање Светске здравствене организације“, Инсајдер, 15. април 2020. https://insajder.net/sr/sajt/vazno/17930/.

- „Западни Балкан тражи од ЕУ да буде изузет из рестрикција за медицинску опрему“, N1, 9. април 2020, http://rs.n1info.com/Vesti/a587383/Zapadni-Balkantrazi-od-EU-da-bude-izuzet-iz-restrikcija-za-medicinsku-opremu.html.

- „Здравствени систем САД на ивици; пацијенти спавају по ходницима“, Б92, 19. јул

.2020 , https://www.b92.net/info/vesti/index.php?yyyy=2020\&mm=07\&dd=19\&nav_categ ory=78\&nav_id $=1708521$.

- „Из пандемије се рађа нови глобални поредак“, Политика, 4. мај 2020.

- „Јурген Хабермас о корони: Толико знања о незнању још никада није било“, Еспресо, 22. април 2020, https://www.espreso.rs/kultura/knjiga/548349/jurgenhabermas-o-koroni-toliko-znanja-o-neznanju-još-nikada-nije-bilo.

- „Како ће земље у развоју преживети?“, Недељник, бр. 55, април 2020.

- „Кина се свим силама труди да оствари двоструку победу - и у превенцији и контроли епидемије и у обнављању рада и производње“, Политика, 22. јун 2020.

- „Кон за РТС: Овај вирус је показао да ништа не знамо о њему“, РТС, 25. јун 2020, https://www.rts.rs/page/stories/ci/\%D0\%9A\%D0\%BE\%D1\%80\%D0\%BE\%D0\%B D\%D0\%B0\%D0\%B2\%D0\%B8\%D1\%80\%D1\%83\%D1\%81/story/3131/koronaviru s-u-srbiji/3998636/koronavirus-predrag-kon-kovid-19-radomir-jankovic.html. 
- „Корона вирус: највећа криза 21. столећа“, Недељник, бр. 431, 2020.

- „Лагард: Пандемија ће убрзати трансформацију европских економија“, РТС, 4. јул

2020. https://www.rts.rs/page/stories/ci/\%D0\%9A\%D0\%BE\%D1\%80\%D0\%BE\%D0\%B D\%D0\%B0\%D0\%B2\%D0\%B8\%D1\%80\%D1\%83\%D1\%81/story/3175/ekonomijai-epidemija/4008583/lagard-pandemija-ekonomija.html.

- „Меркел: Европа се суочава са најтежом ситуацијом у историји“, РТС, 2. јул 2020. https://www.rts.rs/page/stories/ci/\%D0\%9A\%D0\%BE\%D1\%80\%D0\%BE\%D0\%B D\%D0\%B0\%D0\%B2\%D0\%B8\%D1\%80\%D1\%83\%D1\%81/story/3135/koronaviru s-u-svetu/4006692/angela-merkel-koronavirus-evropa-najteza-situacija-uistoriji.html.

- „Моћ Кине је уздрмала цео систем“ 'Монд' без длаке на језику о ЕУ, УН, здравственој кризи: Америка више није вођа света!“, Курир, 1. мај 2020. https://www.kurir.rs/planeta/3456705/moc-kine-je-uzdrmala-ceo-sistem-mondbez-dlake-na-jeziku-o-eu-un-zdravstvenoj-krizi-amerika-vise-nije-vodja-sveta.

- „Научници се слажу: Шведски приступ борби против ковида 19 није успео“, Новости, 24. јул 2020, https://www.novosti.rs/c/planeta/svet/9044475/naucnicislazu-svedski-pristup-borbi-protiv-kovida-19-nije-uspeo.

- „Невидљив, веома мали вирус који изазива расуло“, Б92, 12. јун 2020. https://www.b92.net/info/vesti/index.php?yyyy=2020\&mm=06\&dd=12\&nav_categ ory=78\&nav_id $=1694734$.

- „Ово је крај економије какву смо знали“, Недељник, бр. 56, мај 2020.

- „Ово је тек крај почетка (интервју са др Владимиром Петровићем, епидемиологом)“, Недељник, бр. 438, 2020.

- „Очекује се да Црна Гора измени одлуку о забрани уласка“, Политика, 3. јун 2020.

- „Паралисани италијански туризам“, Недељник, бр. 58, јул 2020.

- „Пауел: Потребан додатни пакет помоћи Конгреса САД“, Радио Слободна Европа, 13. мај 2020, https://www.slobodnaevropa.org/a/30610288.html.

- „Смена владара света пред нашим очима! ЕУ хитно захтева оштрију стратегију према Кини, јер Америка губи у игри престола“, Курир, 25. мај 2020, https://www.kurir.rs/planeta/3470183/smena-vladara-sveta-pred-nasim-ocimaeu-hitno-zahteva-ostriju-strategiju-prema-kini-jer-amerika-gubi-u-igri-prestola.

- „Смена моћи се дешава пред нашим очима! ЕУ хитно захтева оштрију стратегију према Кини, јер Америка губи улогу највеће силе“, Новости, 26. мај 2020. https://www.novosti.rs/vesti/planeta.299.html:866901-Smena-MOCI-sedesava-pred-nasim-ocima-EU-hitno-zahteva-OSTRIJU-strategiju-prema-KINI-jerAmerika-gubi-ulogu-NAJVECE-SILE.

- „Током пандемије у САД без посла остало више од 40 милиона људи“, РТС, 28. мај 2020 , https://www.rts.rs/page/stories/ci/\%D0\%9A\%D0\%BE\%D1\%80\%D0\%BE\%D0\%B D\%D0\%B0\%D0\%B2\%D0\%B8\%D1\%80\%D1\%83\%D1\%81/story/3135/koronaviru 
s-u-svetu/3968723/koronavirus-kovid-19-sjedinjene-americke-drzave-rusija-italijanemacka-francuska-slovenija-bugarska-iran.html.

- „Трамп верује да ће САД ускоро имати вакцину; нове мере на снази у Црној Гори“, $\quad$ РТС, 2.2020. https://www.rts.rs/page/stories/ci/\%D0\%9A\%D0\%BE\%D1\%80\%D0\%BE\%D0\%B D\%D0\%B0\%D0\%B2\%D0\%B8\%D1\%80\%D1\%83\%D1\%81/story/3135/koronaviru s-u-svetu/4005733/koronavirus-svet-2-jul.html.

- „Трамп о пандемији: Корона вирус ће нестати, на крају крајева ћу ја бити у праву“, Курир, 20. јул 2020, https://www.kurir.rs/planeta/3500721/tramp-opandemiji-korona-virus-ce-nestati-na-kraju-krajeva-cu-ja-biti-u-pravu.

- „Трамп: 100 хиљада мртвих био би добро обављен посао“, N1, 30. март 2020. http://rs.n1info.com/Svet/a583395/Tramp-100-hiljada-mrtvih-bio-bi-dobroobavljen-posao.html.

- „Трамп: Прекидамо везе са СЗ0; 'Опасна одлука` ВИДЕО“, Б92, 29. мај 2020. https://www.b92.net/info/vesti/index.php?yyyy=2020\&mm=05\&dd=29\&nav_categ ory=78\&nav_id $=1689459$.

- „У САД више умрлих од короне него жртава у Првом светском рату “, Данас, 16. јун 2020. https://www.danas.rs/svet/u-sad-više-umrlih-od-korone-nego-zrtava-uprvom-svetskom-ratu/.

- „Француски стручњак: Корона је открила фаталну пукотину у ЕУ“, Спутњик Србија, 28. април 2020, https://sptnkne.ws/CkPU.

- „Црна Гора отвара границе за ЕУ, са Србијом остаје затворена“, N1, 30. јун 2020. http://rs.n1info.com/Region/a615144/Crna-Gora-otvara-granicu-sa-EU-sa-Srbijomostaje-zatvorena.html.

- „Швеђанима забрањен улаз у Норвешку, Финску и Данску“, Политика, 24. јун 2020.

- „Шеф Института за вирусологију из Вухана открива све о пореклу корона вируса: Да ли ће ово ставити тачку на теорије завере?“, Новости, 25. мај 2020. https://www.novosti.rs/vesti/planeta.299.html:866877-Sef-Instituta-za-

virusologiju-iz-Vuhana-OTKRIVA-SVE-o-poreklu-korona-virusa-Da-li-ce-ovo-stavititacku-na-TEORIJE-ZAVERE.

- Velika opšta ilustrovana enciklopedija Larousse: Tom 4, Dopunjeno srpsko izdanje, Mono i Manjana, Beograd, 2010.

- Андрејић, Марко, и Ковачевић, Тања. „59 милиона Европљана без посла, масовни банкроти, рецесија: Корона је светској економији ударила незапамћен шамар, шта је следеће: најцрњи сценарио или преокрет“, Блиц, 2. мај 2020. https://www.blic.rs/biznis/privreda-i-finansije/59-miliona-evropljana-bez-poslamasivni-bankroti-recesija-korona-je-svetskoj/fj0n7lp.

- Апостоловски, Александар. „Биле, ковидов сине“, Политика, 19. мај 2020. http://www.politika.rs/scc/clanak/454439/\%D0\%91\%D0\%B8\%D0\%BB\%D0\%B5\%D0\%BA\%D0\%BE\%D0\%B2\%D0\%B8\%D0\%B4\%D0\%BE\%D0\%B2-

\%D1\%81\%D0\%B8\%D0\%BD\%D0\%B5. 
- Бегенишић, Љиљана. „Историчар др Милош Ковић: Ковид 19 показао да само националне државе могу да заштите грађане“, Новости, 30. април 2020. https://www.novosti.rs/vesti/naslovna/drustvo/aktuelno.290.html:862131Istoricar-dr-Milos-Kovic-Kovid-19-pokazao-da-samo-nacionalne-drzave-mogu-dazastite-gradjane.

- Васовић Мекина, Светлана. „Покради ближњег свог“, Печат, бр. 614, 2020.

- Више од 140.000 преминулих у САД; Словенија увела нове мере и у цркви“, РТС, 20.

2020,https://www.rts.rs//page/stories/ci/\%D0\%9A\%D0\%BE\%D1\%80\%D0\%BE\% D0\%BD\%D0\%B0\%D0\%B2\%D0\%B8\%D1\%80\%D1\%83\%D1\%81/story/3135/koro navirus-u-svetu/4023047/koronavirus-svet-zaraženi-kovid-19-pandemija.html.

- Вујић, Тања. „Меркелино „најн“ и Америци и Кини“, Политика, бр. 38270, 2020.

- Вујић, Тања. „ММФ: Криза какву свет није видео“, Политика, 27. јун 2020. http://www.politika.rs/scc/clanak/457157/MMF-Kriza-kakvu-svet-nije-video.

- Г.Т. „Коначно је откривено зашто нико није помогао Италији: Европа је 26. фебруара схватила шта се спрема, а ево како су све државе одреаговале“, Блиц жена, 15. јул 2020. https://zena.blic.rs/lifestile/konacno-je-otkriveno-zasto-nikonije-pomogao-italiji-evropa-je-26-februara-shvatila/0k57gp8.

- Давидов-Кесар, Данијела. „Зараза која не престаје“, Политика, 18. мај 2020. http://www.politika.rs/scc/clanak/454299/Zaraza-koja-ne-prestaje.

- Каваја, Јелена. „Стари митови оживели у новој верзији“, Политика, 18. мај 2020. http://www.politika.rs/scc/clanak/454300/Svet/Stari-mitovi-oziveli-u-novojverziji.

- Лалић, Вељко. „Франсис Фукујама ексклузивно за Недељник: Неолиберализму је одзвонило“, Недељник, 12. април 2020, https://www.nedeljnik.rs/fransisfukujama-ekskluzivno-za-nedeljnik-neoliberalizmu-je-odzvonilo/.

- Мароевић, Раде. „Битка међу државама за маске и респираторе као шпијунски трилер“, $\quad$ РTC, 2.2020 , https://www.rts.rs//page/stories/ci/\%D09A\%.../story3135/koronavirus-u-svetu3940071/koronavirus-svet-maske-nabavka-mosad-vojska.html.

- Митриновић, Биљана. „Меркелова: Не знамо да ли ће либерални систем победити“, $\quad$ Политика, 7.2020 , http://www.politika.rs/scc/clanak/457904/Merekelova-Ne-znamo-da-li-celiberalni-sistem-pobediti.

- Над, Борис. „Америка против Кине: Да ли је „тачка неповрата“ већ пређена“, Печат, бр. 615, 15 мај 2020, http://www.pecat.co.rs/2020/05/da-li-je-tackanepovrata-vec-predjena/.

- Никола, Врзић, „Европска будућност Србије“, Печат, бр. 613, 2020.

- Р.J. „Пола године короне: Потресла је свет из темеља, крај јој се не назире, а на ових 10 кључних питања још немамо одговоре“, Блиц, 6. јул 2020, https://www.blic.rs/vesti/svet/pola-godine-korone-potresla-je-svet-iz-temelja-krajjoj-se-ne-nazire-a-na-ovih-10/gqrchk9. 
- Радишић, Никола. „Грађани Србије од 1. јула могу у Европску унију“, N1, 30. јун 2020. http://rs.n1info.com/Vesti/a615052/Evropska-unija-od-1.-jula-otvaragranice-za-gradjane-Srbije.html.

- Радишић, Никола, „Портпарол ЕК за N1: Објавићемо смернице како поново путовати широм Уније“, $\mathrm{N1}$ (21. април 2020, http://rs.n1info.com/Svet/a591525/Evropski-dopisnik-N1-izvestava-izSengena.html.

- Ракић, Жарко. „Трампу сви криви, највише Кина“, Политика, 17. мај 2020. http://www.politika.rs/scc/clanak/454284/Pogledi/Medunarodnipregled/Trampu-svi-krivi-najvise-Kina.

- Стојаковић, Душан; „Јоже Менцингер: Надам се да је корона крај либералног капитализма, сада и они који не верују у државу од ње траже помоћ“, Новости, 1. мај

2020 ,

https://www.novosti.rs/vesti/naslovna/ekonomija/aktuelno.239.html:862160-JozeMencinger-Nadam-se-da-je-korona-kraj-liberalnog-kapitalizma-sada-i-oni-koji-neveruju-u-drzavu-od-nje-traze-pomoc.

- Чворовић, Горан. „Све више рампи кроз отворену Европску унију: Нико не зна шта га чека ако крене на пут“, Новости, 16. јун 2020. https://www.novosti.rs/vesti/planeta.299.html:870883-Sve-vise-rampi-krozotvorenu--Evropsku-uniju-Niko-ne-zna-sta-ga-ceka-ako-krene-na-put.

- Черкевец, Мирјана. „Због захвалности Кини и Русији, ЕУ прети Србији“, Политика, бр. 38228, 23. април 2020.

- Шундић Миховиловић, Ивана. „Гаранције најефикасније средство против вируса“, Данас, 5. мај 2020, https://www.danas.rs/svet/granice-najefikasnijesredstvo-protiv-virusa/.

\section{NOVEL CORONAVIRUS PANDEMIC: CONSEQUENCES IN THE INTERNATIONAL COMMUNITY}

Abstract: As of beginning of January until the end of July, the Covid19 spread from China to almost all countries of the world, became a pandemic phenomenon, and has infected over 16 million people, with a tendency for the figure to significantly increas. Globally, the virus pandemic has disrupted almost all types of traffic between countries, stopped the movement of people and goods, slowed down the process of globalization, caused problems in the functioning of the economies of almost all countries and led to changes in the economic order. Compared to the United States, China has started its economy faster and established economic cooperation with other countries. Thanks to that, China took over the position of global (economic) leader from the United States. The pandemic has spread to Europe and, with its negative consequences, has put "European ability to stick together" on the test. The reaction of EU Member States to the pandemic has demonstrated that there is no solidarity and unity within the EU and that they 
depend on the degree of interest that its Member States achieve in "negotiating". Such a relationship was also confirmed at the Summit in Brussels, when the amount of money and the manner of its spenditure in the Fund for Aid to the countries affected by the virus, were determined. The Covid19 pandemic has strengthened the role of the state on the national and international stage. The state has become a central place where decisions are made on ways to fight the Covid19 and on measures to protect citizens and improve their life quality. The future of the fight against coronavirus will depend, despite the fragmentation of the international community and the strengthening of the role of the state, on mutual cooperation of states and joint efforts to find a vaccine as the final cure against this, and other viruses.

Key words: COVID-19, pandemic, international community, state, consequences 